\title{
Quantitative estimation of transmembrane ion transport in rat renal collecting duct principal cells
}

\author{
Alexander V. Ilyaskin¹, Denis I. Karpov², Dmitriy A. Medvedev², Alexander P. Ershov', \\ Galina S. Baturina ${ }^{1}$, Liubov E. Katkova ${ }^{1}$ and Evgeniy I. Solenov ${ }^{1,3}$ \\ ${ }^{1}$ Institute of Cytology and Genetics SB RAS, Prospekt Lavrentyeva 10, 630090 Novosibirsk, Russia \\ ${ }^{2}$ Lavrentyev Institute of Hydrodynamics SB RAS, Prospekt Lavrentyeva 15, 630090 Novosibirsk, Russia \\ ${ }^{3}$ Novosibirsk State University, Pirogova st. 2, 630090 Novosibirsk, Russia
}

\begin{abstract}
Kidney collecting duct principal cells play a key role in regulated tubular reabsorption of water and sodium and secretion of potassium. The importance of this function for the maintenance of the osmotic homeostasis of the whole organism motivates extensive study of the ion transport properties of collecting duct principal cells.

We performed experimental measurements of cell volume and intracellular sodium concentration in rat renal collecting duct principal cells from the outer medulla (OMCD) and used a mathematical model describing transmembrane ion fluxes to analyze the experimental data. The sodium and chloride concentrations $\left(\left[\mathrm{Na}^{+}\right]_{\text {in }}=37.3 \pm 3.3 \mathrm{mM},\left[\mathrm{Cl}^{-}\right]_{\text {in }}=32.2 \pm 4.0 \mathrm{mM}\right)$ in OMCD cells were quantitatively estimated. Correspondence between the experimentally measured cell physiological characteristics and the values of model permeability parameters was established. Plasma membrane permeabilities and the rates of transmembrane fluxes for sodium, potassium and chloride ions were estimated on the basis of ion substitution experiments and model predictions. In particular, calculated sodium $\left(P_{\mathrm{Na}}\right)$, potassium $\left(P_{\mathrm{K}}\right)$ and chloride $\left(P_{\mathrm{Cl}}\right)$ permeabilities were equal to $3.2 \times 10^{-6} \mathrm{~cm} / \mathrm{s}$, $1.0 \times 10^{-5} \mathrm{~cm} / \mathrm{s}$ and $3.0 \times 10^{-6} \mathrm{~cm} / \mathrm{s}$, respectively.

This approach sets grounds for utilization of experimental measurements of intracellular sodium concentration and cell volume to quantify the ion permeabilities of OMCD principal cells and aids us in understanding the physiology of the adjustment of renal sodium and potassium excretion.
\end{abstract}

Key words: Renal collecting duct principal cell — Membrane transport — Ion permeability — Pumpleak model

\begin{abstract}
Abbreviations: CD, charge difference approach; DIOA, R-(+)-[(2-n-Butyl-6,7-dichloro-2-cyclopentyl-2,3-dihydro-1-oxo-1H-inden-5-yl)oxy] acetic acid; KCC, $\mathrm{K}^{+}-\mathrm{Cl}^{-}$cotransporter; NKCC, $\mathrm{Na}^{+}-\mathrm{K}^{+}-\mathrm{Cl}^{-}$cotransporter; NMDG, N-methyl-D-glucamine; OMCD, outer medullary collecting duct; PBS, phosphate buffered saline; QN, quasi-neutral approach.
\end{abstract}

\section{Introduction}

The renal collecting duct is a site of sodium reabsorption and potassium secretion, with transport activity regulated

Correspondence to: Alexander V. Ilyaskin, Institute of Cytology and Genetics SB RAS, Prospekt Lavrentyeva 10, 630090 Novosibirsk, Russia

E-mail: ilyaskin@bionet.nsc.ru by aldosterone and antidiuretic hormone $(\mathrm{ADH})$. The principal cells of the kidney collecting duct have to maintain a stable intracellular medium composition and cell volume upon intensive transcellular fluxes of osmolytes and water. There are multiple different pathways involved in the transport of solutes across the cell plasma membrane. Ion transport across principal cells is mediated by sodium (Duc et al. 1994; Bachmann et al. 1999; Loffing and Kaissling 2003; Frindt et al. 2007), potassium (Frindt and 
Palmer 1987; Frindt and Palmer 1989; Muto 2001; Najjar et al. 2005) and chloride (Sansom et al. 1990; Todd-Turla et al. 1996) channels, Na/K-pumps (Feraille and Doucet 2001; Wetzel and Sweadner 2001) and several types of ion transporters (Kuwahara et al. 1991; Chou et al. 2008). It is thus important to quantify the relative contribution of the various transporting mechanisms to the net transmembrane ion flux in order to understand the mechanism of the maintenance of the water-electrolyte balance in a principal cell.

Since investigations of these cells in vivo are difficult due to the complexity of the intact medulla, research is generally focused on in vitro studies of cells in culture and excised fragments of collecting ducts (Burg 1972; Bens and Vandewalle 2008). Fluorescent microscopy and specific fluorescent molecular probes allowing the measurement of intracellular concentration of a wide spectrum of ions are among the most promising experimental techniques for studying cells in vitro (Meuwis et al. 1995; Despa et al. 2000; Jayaraman and Verkman 2000). Fluorescent probes allow for the experimental measurements of ion and water currents in undisturbed, living cells with high accuracy.

During analysis of experimental results obtained using the fluorescent probes one should take into account the complexity and non-linear nature of the interactions between the main cellular characteristics such as cell volume, membrane potential and cell ion content. Another challenge lies in that the experimental data often is not sufficient to estimate all cell physiological properties. A biophysical model could be useful as an instrument for interpretation of the data and extrapolation of the tubule function from experimental conditions to those in vivo. Existing models of principal collecting duct cells made by Weinstein (Weinstein 1997, 1999, 2000, 2001, 2003) were used to simulate the function of the renal epithelium in vivo. Due to their complexity it is impossible to use them as a practical tool to analyze experimental recordings obtained from individual cells.

In this paper we propose an approach to investigate the cell water-electrolyte balance based on experimental measurements of cell volume and ion content and mathematical modeling of transmembrane ion fluxes. Changes of cell volume and intracellular sodium concentration in ion substitution experiments were measured using fluorescent probes. The model used to analyze the experimental data consisted of a system of non-linear differential equations governing the rates of change of cell volume and intracellular amounts of the most important diffusible ions. This approach allowed us to estimate quantitatively the membrane ion permeabilities and the rates of transmembrane ion fluxes in rat renal collecting duct principal cells.

\section{Materials and Methods}

\section{Experimental animals}

All experiments were carried out on Wistar rats weighting 150-200 g (Breeding Laboratory of Experimental Animals, Institute of Cytology and Genetics, Novosibirsk, Russia) according to protocols approved by Bioethics Committee of SB RAS and the EU (86/609/EEC).

\section{Isolated collecting duct fragments}

Rats were anaesthetized by pentobarbital $(50 \mathrm{mg} / \mathrm{kg}$ body weight intraperitoneally). Extracted kidneys were placed in ice-cold phosphate buffered saline (PBS) ( $\mathrm{pH} 7.4$ ), then decapsulated and decorticated. The tissue from the outer medulla zone was squeezed through a needle ( $1.9 \mathrm{~mm}$ i.d.) in the ice-cold calcium-free PBS. The resulting primary suspension was filtered through a nylon mesh and resuspended in L-15 Leibovitz (Sigma-Aldrich, Germany) culture medium. This suspension was used in experiments as a preparation of outer medullary collecting duct (OMCD) fragments.

\section{Solutions}

The solutions used for experiments were based on isotonic PBS (125 mM NaCl, $4.7 \mathrm{mM} \mathrm{Na}_{2} \mathrm{HPO}_{4}, 2.7 \mathrm{mM} \mathrm{KCl}$, $1.5 \mathrm{mM} \mathrm{KH}_{2} \mathrm{PO}_{4}, 0.5 \mathrm{mM} \mathrm{MgCl}_{2}, 5.5 \mathrm{mM}$ glucose, $1 \mathrm{mM}$ $\mathrm{CaCl}_{2} ; 280 \mathrm{mosmol} / \mathrm{kgH}_{2} \mathrm{O}, \mathrm{pH}=7.4$ ). For calcein calibration experiments solutions having different osmolalities $\left(150,300,400,500,600\right.$ mosmol/ $\left.\mathrm{kgH}_{2} \mathrm{O}\right)$ were made on the basis of isotonic PBS: the osmolalities of hypertonic solutions were adjusted with D-mannitol (Sigma, Germany), hypotonic $\left(150 \mathrm{mosmol} / \mathrm{kgH}_{2} \mathrm{O}\right)$ solution was made by 2 fold dilution of $300 \mathrm{mosmol} / \mathrm{kgH}_{2} \mathrm{O}$ solution with distilled water. Calcium-free PBS was used for medullary substance dispersion (125 mM NaCl, $4.7 \mathrm{mM} \mathrm{Na}_{2} \mathrm{HPO}_{4}, 2.7 \mathrm{mM} \mathrm{KCl}$, $1.5 \mathrm{mM} \mathrm{KH}_{2} \mathrm{PO}_{4}, 0.5 \mathrm{mM} \mathrm{MgCl}_{2}, 5.5 \mathrm{mM}$ glucose, $0.05 \mathrm{mM}$ $\left.\mathrm{CaCl}_{2} ; 280 \mathrm{mosmol} / \mathrm{kgH}_{2} \mathrm{O}\right)$. In isotonic $\mathrm{Na}^{+}$substitution experiments $\mathrm{N}$-methyl-D-glucamine-Cl (NMDG-Cl) (ICN Biomedicals, USA) was used instead of $\mathrm{NaCl}$. The calibration of intracellular $\mathrm{Na}^{+}$concentration was performed by incubating the cells in the medium with different $\mathrm{Na}^{+}$concentration: 1) $134.4 \mathrm{mM}$ (normal isotonic PBS); 2) $69.4 \mathrm{mM}$ $\left(60 \mathrm{mM} \mathrm{NaCl}, 4.7 \mathrm{mM} \mathrm{Na} \mathrm{HPO}_{4}, 2.7 \mathrm{mM} \mathrm{KCl}, 1.5 \mathrm{mM}\right.$ $\mathrm{KH}_{2} \mathrm{PO}_{4}, 0.5 \mathrm{mM} \mathrm{MgCl}$, $5.5 \mathrm{mM}$ glucose, $1 \mathrm{mM} \mathrm{CaCl}$, $65 \mathrm{mM}$ NMDG-Cl; $\left.280 \mathrm{mosmol} / \mathrm{kgH}_{2} \mathrm{O}\right)$; 3$) 9.4 \mathrm{mM}(4.7$ $\mathrm{mM} \mathrm{Na}_{2} \mathrm{HPO}_{4}, 2.7 \mathrm{mM} \mathrm{KCl}, 1.5 \mathrm{mM} \mathrm{KH} \mathrm{PO}_{4}, 0.5 \mathrm{mM}$ $\mathrm{MgCl}_{2}$, $5.5 \mathrm{mM}$ glucose, $1 \mathrm{mM} \mathrm{CaCl}$, 125 mM NMDG-Cl; $280 \mathrm{mosmol} / \mathrm{kgH}_{2} \mathrm{O}$ ) in the presence of $10^{-4} \mathrm{M} \mathrm{Na}^{+}$ionophore Nystatin (AppliChem, Germany). In chloride-free solution (4.7 mM Na $2 \mathrm{HPO}_{4}, 4.2 \mathrm{mM} \mathrm{KH_{2 }} \mathrm{PO}_{4}, 5.5 \mathrm{mM}$ glucose, $125 \mathrm{mM} \mathrm{Na}$-gluconate, $0.5 \mathrm{mM} \mathrm{MgSO}_{4}, 1.0 \mathrm{mM}$ 
Ca D-gluconate; 280 mosmol/ $\left.\mathrm{kgH}_{2} \mathrm{O}\right) \mathrm{NaCl}$ was substituted by Na D-gluconate (ICN Biomedicals, USA). DIOA $\left(10^{-4}\right.$ $\mathrm{M}$ in isotonic $\mathrm{PBS})$ or bumetanide $\left(10^{-5} \mathrm{M}\right.$ in isotonic $\left.\mathrm{PBS}\right)$ (Sigma, Germany) was used for inhibition of KCC or NKCC cotransporters, respectively.

\section{Experimental setup for fluorescence microscopy}

Experiments on isolated collecting duct segments were performed in a superfusion chamber. The key characteristics of the superfusion chamber were:

- dimensions of channels: $1 \times 0.5 \mathrm{~mm}$

- fluid flow rate: $2 \mathrm{ml} / \mathrm{min}$

- characteristic time of solution exchange: less than $200 \mathrm{~ms}$

- thermal stabilization at $36.8 \pm 0.2^{\circ} \mathrm{C}$.

The experimental setup was built on an upright fluorescence microscope LOMO-P8 (LOMO, St. Petersburg, Russia) with a water immersion objective $(\times 70$, N.A. 1.23$)$ and thermostabilized stage. The suspension of OMCD fragments in $100 \mu \mathrm{l}$ of L-15 Leibovitz medium was placed on a cover glass covered with poly-D-lysine (Sigma-Aldrich, Germany) and then cells were loaded with fluorescent dye. The filter settings used were: $490 \mathrm{~nm}$ excitation filter, $500 \mathrm{~nm}$ dichroic mirror, 520 emission filter.

The emitted light was detected by photomultiplier (PMT79 , Russia) with an adjustable diaphragm that allowed us to select the cells of interest. The signal was registered by an Aktakom ACK-3102 digital oscilloscope (Aktakom, Russia) and stored on a PC.

Fluorescence measurements of cell volume were performed by the calcein quenching method as it was previously described (Solenov et al. 2004). Cells were loaded with calcein AM (Sigma-Aldrich, Germany) $\left(10^{-6} \mathrm{M}\right.$ in L-15 Leibovitz medium, DMSO 1\%) by incubation for 10 15 minutes at $37^{\circ} \mathrm{C}$. Measurements of intracellular sodium concentration $\left[\mathrm{Na}^{+}\right]_{\text {in }}$ were conducted using the fluorescent dye Sodium Green (Invitrogen, USA). Cells were loaded with $10^{-6} \mathrm{M}$ sodium green tetraacetate (Invitrogen, USA) for $40 \mathrm{~min}$ at $37^{\circ} \mathrm{C}$.

\section{Calcein fluorescence calibration}

Calcein fluorescence was calibrated as it was previously described in detail (Zarogiannis et al. 2013). In short, the Calcein fluorescence and cell height of superfused OMCD fragments were measured simultaneously when the cells were challenged by various osmolalities of the extracellular medium $\left(150,300,400\right.$ and $\left.600 \mathrm{mosmol} / \mathrm{kgH}_{2} \mathrm{O}\right)$.

The relationship between cell height and cell volume was studied in the primary culture of OMCD cells. These experiments were described in our previous paper (Zarogiannis et al. 2013). 3D confocal reconstructions were performed for cells balanced in solutions having different osmolalities
(300, 400, 500 and 600 mosmol/ $\left.\mathrm{kgH}_{2} \mathrm{O}\right)$. Hypotonic medium caused rapid regulatory cell volume decrease (RVD) of these cells (Ilyaskin et al. 2011; Zarogiannis et al. 2013) and $3 \mathrm{D}$ confocal reconstruction in hypotonic solution was not performed. On the basis of 3D confocal reconstructions in solutions of different osmolalities, the assumption that OMCD cell volume is proportional to cell height cubed could be accepted: $V / V_{0}=\left(H / H_{0}\right)^{3}$. Also, according to the results of Calcein calibration experiments on the OMCD principal cells (Zarogiannis et al. 2013) and model simulations (unpublished data), we conclude that the apparent osmotically inactive portion of cell volume does not exceed $10 \%$ of the total cell volume. Taking into account that the osmotically inactive volume has a dynamic nature, it could not be determined precisely using an experimental approach. Thus it was neglected in all model calculations.

\section{Methods of mathematical modeling}

The mathematical model used in the present work is similar to that proposed in Fraser and Huang (2004), Ilyaskin et al. (2011), Zarogiannis et al. (2013). The model includes a set of ordinary differential equations, which describe the changes of the cell volume $V$ and intracellular amounts of $\mathrm{K}^{+}, \mathrm{Na}^{+}$, and $\mathrm{Cl}^{-}\left(n_{\mathrm{Na}}, n_{\mathrm{K}}, n_{\mathrm{Cl}}\right)$ due to the transmembrane fluxes of ions and water through their respective channels and the Na/K-pump (Fig. 1). As the experiments were performed on principal cells from the open-end portion of the collecting duct fragments, where the single epithelial layer

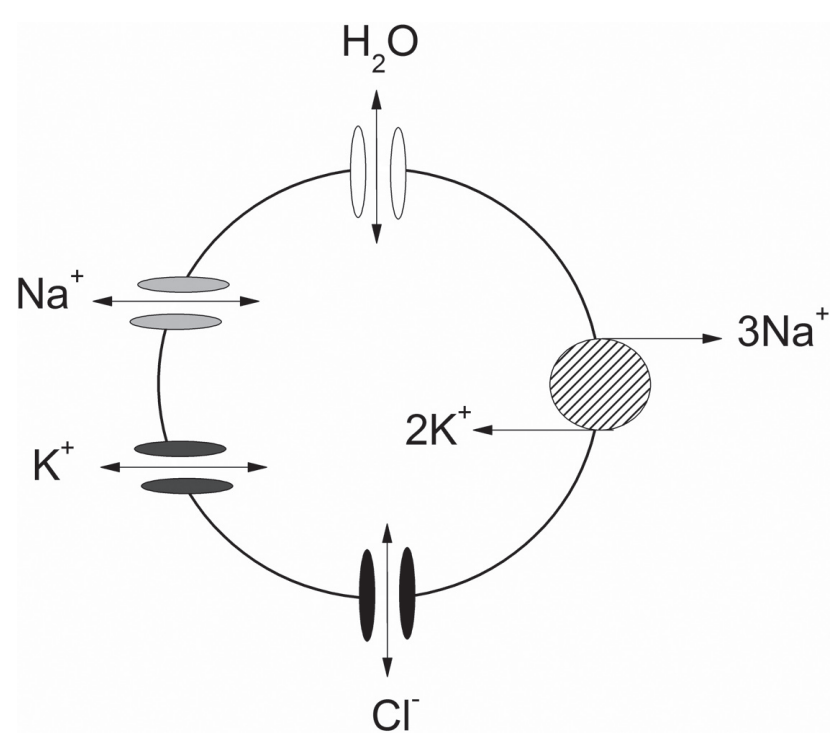

Figure 1. The schematic diagram of water and ion transport pathways included in the model of an OMCD principal cell. The scheme includes water $\left(\mathrm{H}_{2} \mathrm{O}\right)$ and ion $\left(\mathrm{Na}^{+}, \mathrm{K}^{+}, \mathrm{Cl}^{-}\right)$channels and $\mathrm{Na}^{+} / \mathrm{K}^{+}$-pump with $3 \mathrm{Na}^{+} / 2 \mathrm{~K}^{+}$stoichiometric ratio. 
Table 1. Symbols of parameters and variables and their values used in the model

\begin{tabular}{|c|c|c|}
\hline Variables & & \\
\hline Cell volume & $V$ & \multirow{9}{*}{ Depend on the values of permeability parameters } \\
\hline Intracellular $\mathrm{Na}^{+}$concentration & {$\left[\mathrm{Na}^{+}\right]_{\text {in }}$} & \\
\hline Intracellular amount of $\mathrm{Na}^{+}$ & $n_{\mathrm{Na}}$ & \\
\hline Intracellular $\mathrm{K}^{+}$concentration & {$\left[K^{+}\right]_{\text {in }}$} & \\
\hline Intracellular amount of $\mathrm{K}^{+}$ & & \\
\hline Intracellular $\mathrm{Cl}^{-}$concentration & {$\left[\mathrm{Cl}^{-}\right]_{\text {in }}$} & \\
\hline Intracellular amount of $\mathrm{Cl}^{-}$ & $n_{C l}$ & \\
\hline Transmembrane potential difference & $E_{m}$ & \\
\hline \multicolumn{2}{|l|}{ Parameters } & \\
\hline Intracellular amount of organic anions & $n_{X}$ & $8.3 \times 10^{-14} \mathrm{~mol}$ \\
\hline Cell surface area & $A$ & $1 \times 10^{-5} \mathrm{~cm}^{2}$ \\
\hline \multirow{2}{*}{ Integration step } & \multirow{2}{*}{$d t$} & $1 \times 10^{-5} \mathrm{~s}(\mathrm{CD}$ method $)$ \\
\hline & & $1 \times 10^{-2} \mathrm{~s}(\mathrm{QN}$ method $)$ \\
\hline Membrane $\mathrm{Na}^{+}$permeability & $P_{\mathrm{Na}}$ & Based on the experimental data ${ }^{*}$ \\
\hline Membrane $\mathrm{K}^{+}$permeability & $P_{K}$ & Based on the experimental data ${ }^{*}$ \\
\hline Membrane $\mathrm{Cl}^{-}$permeability & $P_{C l}$ & Based on the experimental data ${ }^{*}$ \\
\hline Membrane osmotic water permeability & $P_{W}$ & $2 \times 10^{-1} \mathrm{~cm} / \mathrm{s}$ \\
\hline Total Na/K-pump membrane density & $N_{\text {pump }}$ & Based on the experimental data ${ }^{*}$ \\
\hline Extracellular $\mathrm{Na}^{+}$concentration & {$\left[\mathrm{Na}^{+}\right]_{\text {out }}$} & $134.4 \mathrm{mM}$ \\
\hline Extracellular $\mathrm{K}^{+}$concentration & {$\left[K^{+}\right]_{\text {out }}$} & $4.2 \mathrm{mM}$ \\
\hline Extracellular $\mathrm{Cl}^{-}$concentration & {$\left[\mathrm{Cl}^{-}\right]_{\text {out }}$} & $130.7 \mathrm{mM}$ \\
\hline Total extracellular concentration of osmolytes & $\Pi_{e}$ & $280 \mathrm{mM}$ \\
\hline Membrane capacitance & $C_{m}$ & $7 \times 10^{-7} \mathrm{~F} / \mathrm{cm}^{2}$ \\
\hline Mean organic osmolyte valence & $z$ & -1.5 \\
\hline Partial molar volume of water & $V_{W}$ & $18 \mathrm{~cm}^{3} / \mathrm{mol}$ \\
\hline Faraday's constant & $F$ & $96485 \mathrm{C} / \mathrm{mol}$ \\
\hline Absolute temperature & $T$ & $310 \mathrm{~K}$ \\
\hline Gas constant & $R$ & $8.31 \mathrm{~J} / \mathrm{K} \cdot \mathrm{mol}$ \\
\hline
\end{tabular}

* the final values of these variables and parameters are shown in Table 2. Parameters of the $\mathrm{Na} / \mathrm{K}$-pump model are presented in Table 4 (Appendix).

of cells was well-stirred, the simple "symmetrical" model could be used.

The set of membrane osmolyte carriers and transporters taken into account in the model was chosen according to expression patterns in collecting duct cells (Frindt and Palmer 1987, 1989; Duc et al. 1994; Bachmann et al. 1999; Feraille and Doucet 2001; Muto 2001; Najjar et al. 2005; Pisitkun et al. 2006; Chou et al. 2008; Uawithya et al. 2008; Wakamatsu et al. 2009). The transport of osmolytes and water depended on the area of the cell surface $A$, which was assumed to be constant and independent of cellular volume because of the low extensibility of the lipid bilayer. The symbols of main parameters and variables and their values are listed in Table 1, and Table 4 (in Appendix).

The equations of the model are the same as in (Zarogiannis et al. 2013):

$$
\frac{d n_{N a}}{d t}=A\left(-3 J_{\text {pump }}+J_{N a}+J_{N K C C}\right)
$$

$$
\begin{aligned}
& \frac{d n_{K}}{d t}=A\left(2 J_{p u m p}+J_{K}+J_{K C C}+J_{N K C C}\right) \\
& \frac{d n_{C l}}{d t}=A\left(J_{C l}+J_{K C C}+2 J_{N K C C}\right) \\
& \frac{d V}{d t}=A V_{W} P_{W}\left(\frac{n_{N a}+n_{K}+n_{C l}+n_{X}}{V}-\Pi_{e}\right)
\end{aligned}
$$

This system was used to simulate both the steady state of the cell (a state reached asymptotically after a sufficiently long time for given permeability parameters) and transient reactions of the cell to the changes of the outer medium.

The passive ion fluxes through channels were modeled using the Goldman-Hodgkin-Katz expression (Goldman 1943; Hodgkin and Katz 1949):

$$
J_{N a}=P_{N a} \varepsilon(u)\left[\left[N a^{+}\right]_{o u t} \exp \left(-\frac{u}{2}\right)-\left[N a^{+}\right]_{\text {in }} \exp \left(\frac{u}{2}\right)\right]
$$




$$
\begin{aligned}
& J_{K}=P_{K} \varepsilon(u)\left[\left[K^{+}\right]_{\text {out }} \exp \left(-\frac{u}{2}\right)-\left[K^{+}\right]_{\text {in }} \exp \left(\frac{u}{2}\right)\right] \\
& J_{C l}=P_{C l} \varepsilon(u)\left[\left[C l^{-}\right]_{\text {out }} \exp \left(\frac{u}{2}\right)-\left[C l^{-}\right]_{\text {in }} \exp \left(-\frac{u}{2}\right)\right]
\end{aligned}
$$

where $u=F E_{m} / R T$, and $\varepsilon(u)=u /(\exp (u / 2)-\exp (-u / 2))$.

The flux through the $\mathrm{Na} / \mathrm{K}$-pump $\left(J_{\text {pump }}\right)$ was derived from the kinetic model described in Hernandez et al. (1989) using rate constants and other parameters of the $\mathrm{Na} / \mathrm{K}$-pump presented in Hernandez and Chifflet (2000). Flux through the $\mathrm{Na} / \mathrm{K}$-pump $\left(J_{\text {pump }}\right)$ was calculated according to the formula:

$$
J_{\text {pump }}=\frac{1}{\Sigma} N_{\text {pump }}(\alpha-\beta)
$$

where $N_{\text {pump }}$ is the membrane pump density, $\alpha$ is the function of forward rate constants, $\beta$ is the function of backward rate constants, and $\Sigma$ is the function of all rate constants and the ligand concentrations implemented in the kinetic scheme (Hernandez et al. 1989). Thus the fluxes of $\mathrm{Na}^{+}$and $\mathrm{K}^{+}$(positive in the inward direction) are equal to $-3 J_{\text {pump }}$ and $2 J_{\text {pump }}$, respectively. The detailed description of the $\mathrm{Na} / \mathrm{K}$-pump model is shown in the Appendix.

In contrast to our early version of the model (Ilyaskin et al. 2011), in the current paper as well as in Zarogiannis et al. (2013) the ion fluxes through cotransporters KCC $\left(\mathrm{K}^{+}\right.$$\mathrm{Cl}^{-}$cotransporter) and $\mathrm{NKCC}\left(\mathrm{Na}^{+}-\mathrm{K}^{+}-\mathrm{Cl}^{-}\right.$cotransporter $)$ were set to zero $\left(J_{K C C}=J_{N K C C}=0\right)$ according to experimental data on their activity in OMCD principal cells (see Results section).

Osmotic water flux was included in the model by the parameter of membrane water permeability $\left(P_{w}\right)$ and the rate of cell volume changes. The value of $P_{w}$ typical for OMCD cells was set equal to the value estimated in our previous work (Ilyaskin et al. 2011).

Extracellular osmolarity $\Pi_{e}$ was defined according to the experimental protocol while the intracellular osmolarity was equal to the sum of the $\mathrm{Na}^{+}, \mathrm{K}^{+}, \mathrm{Cl}^{-}$and organic ion concentrations. The amount of organic anions $\left(n_{X}\right)$ was chosen so that the calculated stationary cell volume $V$ was close to the size of OMCD cells $\left(\sim 1 \times 10^{-9} \mathrm{~cm}^{3}\right)$. The mean charge of organic anions $z$ was set equal to -1.5 according to assumptions made by Fraser (Fraser and Huang 2004) to balance steady-state intracellular cation concentrations typical for OMCD cells (Gifford et al. 1990).

An important variable of the model is transmembrane potential difference $E_{m}$ which affects all essential fluxes. $E_{m}$ was calculated at each time step using one of the two different approaches. In the first one, called the charge difference $(C D)$ method, $E_{m}$ was expressed directly through the membrane capacitance $\left(C_{m}\right)$ and the total intracellular charge as discussed by Fraser and Huang previously (Fraser and Huang 2004):

$$
E_{m}=F\left(n_{N a}+n_{K}-n_{C l}+z n_{X}\right) / C_{m} A
$$

The differential equations were solved numerically with the high-precision fourth order Runge-Kutta method, and with the sufficiently small time step $d t=10^{-5}$ seconds. This value is about five orders of magnitude smaller than the characteristic time of simulated processes (usually several seconds). The special tests with $d t=10^{-6} \mathrm{~s}$ showed no noticeable change of the results. Hence, the value $d t=10^{-5} \mathrm{~s}$ was small enough to provide accurate calculations.

The second approach (further referred to as quasi-neutral, or QN) to calculate $E_{m}$ employed a condition of approximate electroneutrality of the intracellular medium. As proposed in (Hernandez and Chifflet 2000), the total current balance was set to zero:

$$
-J_{\text {pump }}+J_{N a}+J_{K}-J_{C l}=0
$$

This transcendental equation for $E_{m}$ was solved at each time step (the procedure is presented in the Appendix).

Both approaches gave similar results for steady state as well as for dynamic calculations (the relative deviation between calculations did not exceed $0.04 \%$ ). It should be noted that the QN approach permits one to use 1000-fold larger time steps $\left(d t=1 \times 10^{-2} \mathrm{~s}\right)$ resulting in much faster calculations. The agreement of both methods supports the confidence in their output.

The following initial values of variables were used to calculate the correspondence table between model permeability parameters and steady-state characteristics: $V=1.0$ $\times 10^{-9} \mathrm{~cm}^{3} ; n_{\mathrm{Na}}=3.075 \times 10^{-14} \mathrm{~mol} ; n_{\mathrm{K}}=1.3 \times 10^{-13} \mathrm{~mol}$; $n_{C l}=3.625 \times 10^{-14} \mathrm{~mol}$. These values were chosen to satisfy the electroneutrality condition of intracellular medium and to ensure transmembrane osmotic balance.

The correspondence table between values of permeability parameters and values of stationary state characteristics of the model was obtained by systematic calculation of steady state characteristics for the broad range of permeability parameter values $\left(P_{N a}, P_{K}\right.$ and $\left.N_{\text {pump }}\right)$. This goal was accomplished with the use of the high-performance computer cluster HKC-30T (Siberian Supercomputer Center, Institute of Computational Mathematics and Mathematical Geophysics SB RAS). First, we specified the subrange of the parameter values for which the system could reach steady state. The system was assumed to reach steady state if the conditions: $\frac{d \ln x}{d t} \mid<1.0 \times 10^{-7} \mathrm{~s}^{-1}$ were satisfied, where $x$ is the cell volume $V$ or intracellular amount of ions $n_{i}\left(i=\mathrm{Na}^{+}\right.$, $\mathrm{K}^{+}$or $\mathrm{Cl}^{-}$). If the virtual time exceeded $1.5 \times 10^{5}$ seconds (i.e. number of integration steps using the $\mathrm{CD}$ equation exceeded $1.5 \times 10^{10}$ ) and at least one of the above conditions remained 
unsatisfied, it was considered that the system was unable to reach steady state with the given parameter values.

If steady state was reached, the results could be checked by solving the steady-state equations directly, i.e. setting to zero the right-hand parts of Eqs. (1-4). As in a non-stationary asymptotic approach, we neglected the fluxes through cotransporters (KCC and NKCC). After some transformations of Eqs. $(1-4,9)$ one has the system:

$$
\begin{aligned}
& J_{C l}=0 \\
& 2 J_{N a}+3 J_{K}=0 \\
& \left(\frac{n_{N a}}{V}+\frac{n_{K}}{V}\right)(1-z)-\frac{n_{C l}}{V}(1+z)=\frac{A C_{m} E_{m}}{F V}-z \Pi_{e} \\
& -3 J_{p u m p}+J_{N a}=0 \\
& \left(\frac{n_{N a}+n_{K}+n_{C l}+n_{X}}{V}\right)-\Pi_{e}=0
\end{aligned}
$$

Since the QN approximation was found to be satisfactory, for the stationary system we used only the quasi-neutral approximation which formally corresponds to $C_{m}=0$ case in Eq. (13). According to expressions (5-7), the first three equations of the system (11-15) are linear in concentrations $\left(n_{i} / V\right)$ of chloride, sodium and potassium ions inside the cell, and for $C_{m}=0$ these concentrations can be expressed explicitly through $E_{m}$. For chloride concentration one has immediately from (7) and (11):

$$
\frac{n_{C l}}{V}=\left[C l^{-}\right]_{o u t} \exp \left(\frac{F E_{m}}{R T}\right)
$$

For concentrations of $\mathrm{Na}^{+}$and $\mathrm{K}^{+}$from (5), (6) and (12), (13):

$$
\begin{aligned}
& 2 P_{N a} \cdot \frac{n_{N a}}{V}+3 P_{K} \cdot \frac{n_{K}}{V}=\left(2 P_{N a} \cdot\left[N a^{+}\right]_{o u t}+\right. \\
& \left.+3 P_{K} \cdot\left[K^{+}\right]_{\text {out }}\right) \exp \left(-\frac{F E_{m}}{R T}\right) \equiv B \\
& \frac{n_{N a}}{V}+\frac{n_{K}}{V}=\left(\frac{n_{C l}}{V} \frac{(1+z)}{1-z}-\frac{z \Pi_{e}}{1-z}\right)=D
\end{aligned}
$$

A single unknown $E_{m}$ remains in both $B$ and $D$ (in the latter through the $n_{C l} / V$ correlation written above). The two equations give:

$$
\begin{gathered}
\frac{n_{N a}}{V}=\frac{B-3 P_{K} \cdot D}{2 P_{N a}-3 P_{K}} \\
\frac{n_{K}}{V}=\frac{2 P_{N a} \cdot D-B}{2 P_{N a}-3 P_{K}}
\end{gathered}
$$

Note that both $\mathrm{Na}^{+}$and $\mathrm{K}^{+}$intracellular concentrations are in fact expressed through $E_{m}$ only. Since the pump flux depends on $E_{m}$ and on sodium and potassium concentrations, Eq. (14) is effectively an equation for the single unknown $E_{m}$. It was solved numerically, and then internal concentrations were computed. Finally, the last equation (15) produced the cell volume $V$ which defined the steady-state quantity of ions $\left(n_{i} / V\right)$.

For all parameter values (in the subrange of the parameter values for which the system could reach steady state) the relative deviation (\%) between asymptotic and direct steady state solutions given by:

$$
\text { dev }=\frac{\left|x_{\text {asympt }}-x_{\text {direct }}\right|}{x_{\text {direct }}} \times 100 \%
$$

where $x_{\text {asympt }}$ is asymptotic steady state solution for cell volume $V$, intracellular amount of $\mathrm{Na}^{+}, \mathrm{K}^{+}$or $\mathrm{Cl}^{-} ; x_{\text {direct }}$ is direct steady state solution for cell volume $V$, intracellular amount of $\mathrm{Na}^{+}, \mathrm{K}^{+}$or $\mathrm{Cl}^{-}$didn't exceed $0.3 \%$. In conclusion, the steady state solutions of all three approaches (timedependent approach using CD equation, time-dependent approach using QN equation and direct approach) were in good agreement.

To determine the absolute values of sodium, potassium and chloride permeability, the behaviour of a cell subjected to the external medium with ion content changed according to the appropriate protocol was compared with the model predictions. Specifically, the model parameters were estimated by fitting the experimental and model dynamics of intracellular sodium concentration (for sodium and potassium permeabilities) and relative cell volume (for chloride permeability).

\section{Statistics}

Data are presented as means $(\mathrm{M}) \pm$ standard error $(\mathrm{SE})$.

\section{Results}

Effect of inhibitors of cotransporters on principal OMCD cell volume in isotonic medium

The estimation of NKCC and KCC activity was made based on the effect of inhibitors of cotransporters on cell volume in isotonic medium. Inhibition of KCC by DIOA resulted in $~ 1 \%$ increase of cell volume $(1.013 \pm 0.004, n=5)$ (Fig. 2). The effect of the NKCC inhibitor bumetanide was undetectable in our experiments $(n=5)$ (Fig. 3$)$. As the effect of both inhibitors resulted in insignificant changes of cell volume, the contribution of NKCC and KCC cotransporters to the net transmembrane ion flux in OMCD cells was assumed to be zero. 


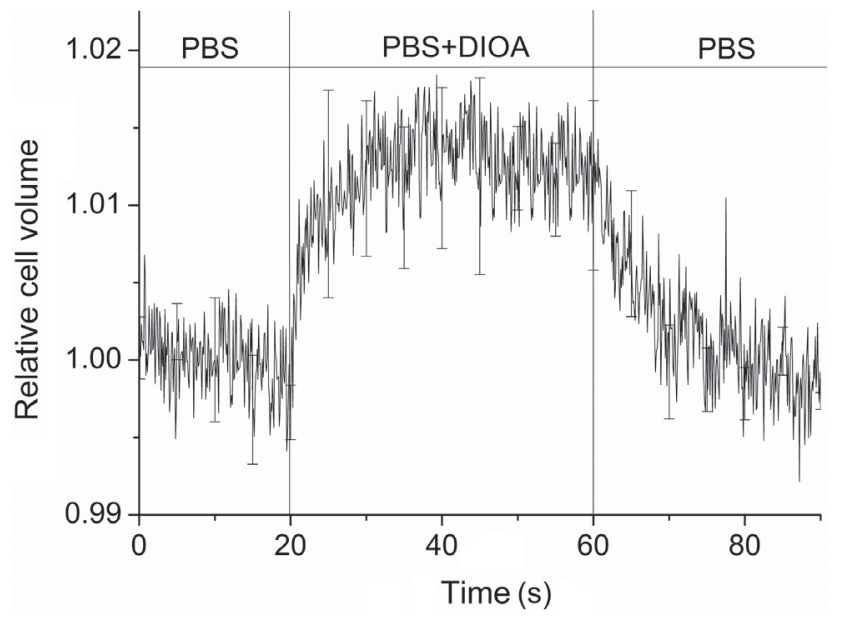

Figure 2. Effect of the KCC inhibitor DIOA $\left(10^{-4} \mathrm{M}\right)$ on the relative volume $\left(V / V_{0}\right)$ of $\mathrm{OMCD}$ principal cells in isotonic medium. DIOA, R-(+)-[(2-n-Butyl-6,7-dichloro-2-cyclopentyl-2,3dihydro-1-oxo-1H-inden-5-yl)oxy]acetic acid. PBS, phosphate buffered saline.

Intracellular sodium concentration in principal OMCD cells

Stationary sodium concentration in OMCD principal cells was measured using the fluorescent approach. The signal was calibrated by exposing the cells to bath solution with different $\mathrm{Na}^{+}$concentrations $(134.4 \mathrm{mM}, 69.4 \mathrm{mM}$ or $9.4 \mathrm{mM})$ in the presence of $10^{-4} \mathrm{M} \mathrm{Na}^{+}$ionophore nystatin that made it possible to control the internal sodium concentration. Fig. 4 shows the typical experimental measurement of relative Sodium Green fluorescence in OMCD cells. Thus the quan-

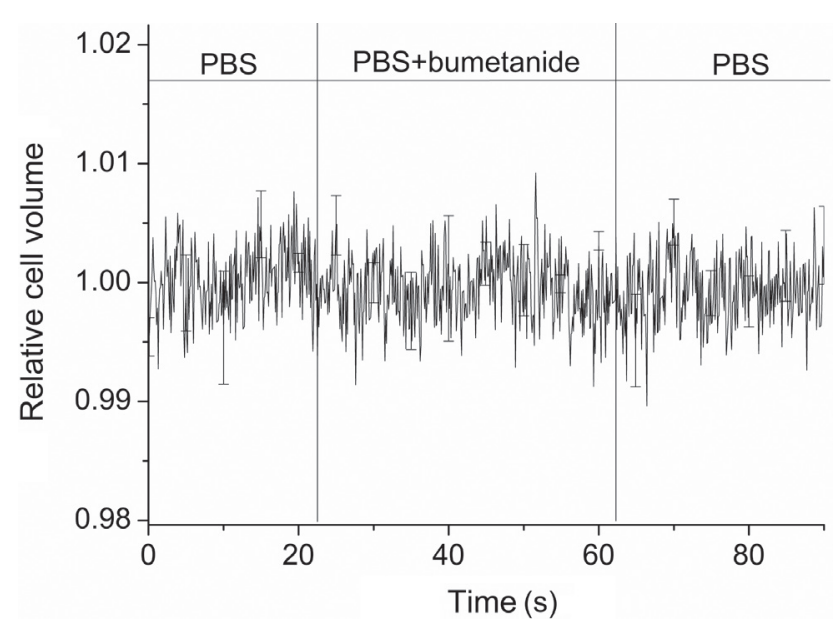

Figure 3. Effect of the NKCC inhibitor bumetanide $\left(10^{-5} \mathrm{M}\right)$ on the relative volume of OMCD principal cells $\left(V / V_{0}\right)$ in isotonic medium. PBS, phosphate buffered saline.

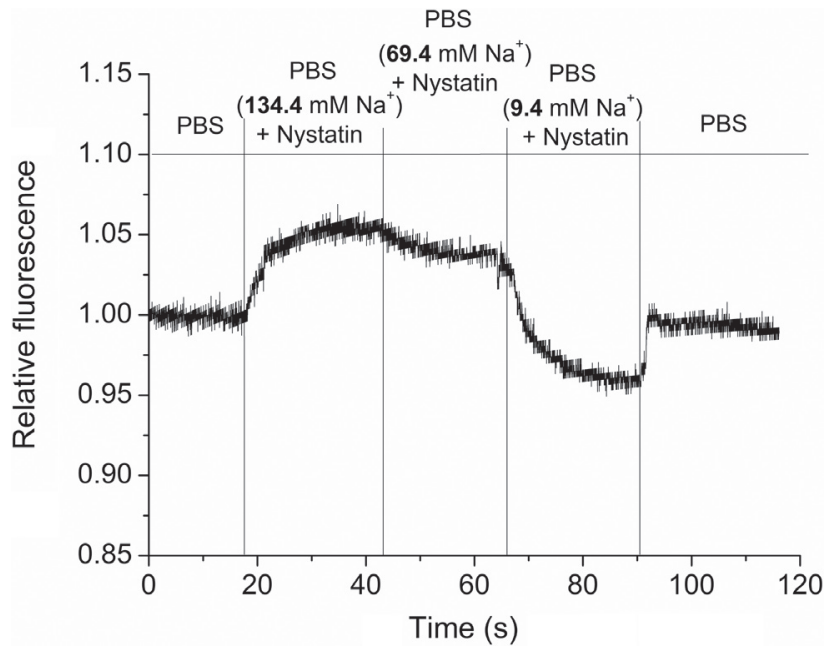

Figure 4. The estimation of intracellular sodium concentration $\left[\mathrm{Na}^{+}\right]_{\text {in }}$. Typical dynamics of the relative fluorescence $\left(F / F_{0}\right)$ of Sodium Green dye sensitive to intracellular sodium concentration changes. The sequence of bath solutions used for calibration is indicated above the experimental curve. PBS, phosphate buffered saline.

titative estimation of the sodium concentration in OMCD cells is $\left[\mathrm{Na}^{+}\right]_{\text {in }}=37.3 \pm 3.3 \mathrm{mM}(n=10)$.

Intracellular chloride concentration in principal OMCD cells

An indirect approach was used to measure the cellular chloride concentration $\left[\mathrm{Cl}^{-}\right]_{i n}$, which was based on the amplitude of relative cell volume decrease in $\mathrm{Cl}$-free medium. Cells in $\mathrm{Cl}$-free solution equilibrated to the relative cell volume of $0.77 \pm 0.03(n=10)$ (Fig. 5). The Cl-free medium drives nearly all $\mathrm{Cl}^{-}$ions out of a cell, and the flux of negatively charged chloride ions is coupled with positively charged ions to maintain electroneutrality. Therefore, the intracellular chloride content could be estimated as $11.5 \%$ of the total cellular osmolyte content, or $32.2 \pm 4.0 \mathrm{mM}$, assuming that the total intracellular ion concentration is $280 \mathrm{mM}$. This value should be treated as a rough estimate based on three assumptions: 1) the greatest part of the OMCD principal cell volume is osmotically active (see Materials and Methods); 2) the cell plasma membrane is impermeable to D-gluconate; 3 ) the intracellular amount of organic anions remains constant when the cell is challenged by $\mathrm{Cl}$-free medium.

\section{Application of a biophysical model for analysis of experimental data}

Water and electrolyte homeostasis in real cell corresponds to the steady state of the model system. The steady state solution of the system (steady state values of $n_{\mathrm{Na}}, n_{K}, n_{\mathrm{Cl}}$ and $V$ ) allows one to calculate nine physiologically meaningful 


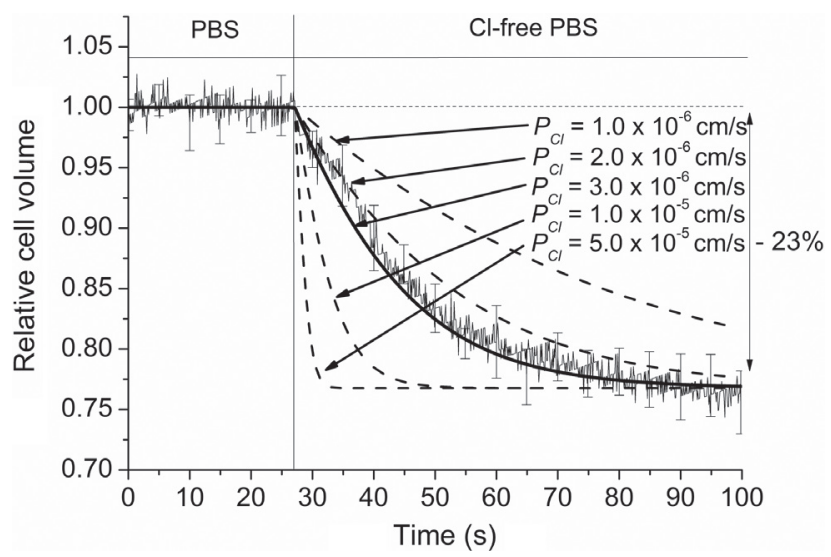

Figure 5. The dynamics of relative volume of OMCD principal cells $\left(V / V_{0}\right)$ superfused by the $\mathrm{Cl}$-free medium (mean $\left.\pm \mathrm{SE}, n=10\right)$. The amplitude of the cell volume decrease allows one to estimate the intracellular chloride concentration. The rate of cell shrinkage was used for estimation of membrane chloride permeability $P_{C l}$. The results of the modeling of cell volume dynamics in $\mathrm{Cl}$-free solution are shown by dashed lines. The solid line shows the best-fit result of modeling to the experimental curve. The corresponding absolute values of $P_{C l}$ are shown above the curves. PBS, phosphate buffered saline.

variables which will be referred to as the characteristics of the steady state. The list of characteristics includes intracellular concentrations of sodium, potassium, chloride and organic ions $\left(\left[\mathrm{Na}^{+}\right]_{i n},\left[\mathrm{~K}^{+}\right]_{i n},\left[\mathrm{Cl}^{-}\right]_{i n},\left[\mathrm{X}^{Z}\right]_{i n}\right)$, transmembrane electric potential difference $\left(E_{m}\right)$, cell volume $(V)$, passive fluxes of sodium and potassium ions $\left(\mathrm{JNa}_{\mathrm{Na}}, J_{\mathrm{K}}\right)$ and flux through $\mathrm{Na} / \mathrm{K}$-ATPase $\left(J_{\text {pump }}\right)$.

We investigated the dependence of steady state characteristics on the permeability parameters. The permeability parameters of the model are coefficients in equations of electrodiffusion $\left(P_{\mathrm{Na}}, P_{K}, P_{C l}\right)$ and surface density of $\mathrm{Na} / \mathrm{K}$ ATPase $\left(N_{\text {pump }}\right)$. Despite the fact that other free parameters such as $z$ (mean organic osmolyte valence) and $n_{X}$ (intracellular amount of organic anions) have an influence on the values of steady state characteristics (Fraser and Huang 2004), the investigation of the their impact on the model behavior was out of the scope of the current work and thus their values were kept constant (see "Methods of mathematical modeling" in Materials and Methods section).

The numerical solution of the system (1-4) was performed in a wide range of permeability parameter values in order to find the parameter values consistent with the steady states of the system. To create the correspondence table between permeability parameters and stationary state characteristics of the model the value of chloride permeability was set arbitrarily: $P_{C l}=1.0 \times 10^{-6} \mathrm{~cm} / \mathrm{s}$. It should be noted that $P_{C l}$ has no influence on the steady state characteristics due to the absence of cotransport activity. Thus, the state of the model system was described by the values of three permeability parameters, namely, $P_{\mathrm{Na}}, P_{\mathrm{K}}$ and $N_{\text {pump }}$. These parameters in fact define the transmembrane ion gradients, transmembrane potential and the intracellular medium composition.

Under the assumption that the contribution of KCC and NKCC cotransporters to the total transmembrane flux is insignificant, the passive flux of chloride ions in steady state is zero $\left(J_{C l}=0\right)$ and the intracellular chloride concentration $\left[\mathrm{Cl}^{-}\right]_{\text {in }}$ can be calculated from the value of membrane potential $E_{m}$ according to Nernst equation:

$$
\left[\mathrm{Cl}^{-}\right]_{\text {in }}=\left[\mathrm{Cl}^{-}\right]_{\text {out }} \exp \left(\frac{E_{m} F}{R T}\right)
$$

Also, it should be noted that proportional changing of all ion contents $\left(n_{N a}, n_{K}, n_{C l}\right.$ and $\left.n_{X}\right)$ causes proportional changes of the set point of cell volume $V$, but does not influence other steady state characteristics (intracellular ion concentrations, membrane potential and transmembrane ion fluxes). Thus, when investigating the dependence of steady state characteristics on the permeability parameters, the cell volume $V$ can be ignored and eliminated from the list of steady state characteristics. In addition, the simple equations considering the osmotic equilibrium and gross electroneutrality

$$
\begin{aligned}
& {\left[\mathrm{Na}^{+}\right]_{i n}+\left[\mathrm{K}^{+}\right]_{\text {in }}+[\mathrm{Cl}]_{\text {in }}+\left[\mathrm{X}^{z}\right]_{\text {in }}=280 \mathrm{mM}} \\
& {\left[\mathrm{Na}^{+}\right]_{\text {in }}+\left[\mathrm{K}^{+}\right]_{\text {in }}=[\mathrm{Cl}]_{\text {in }}-z\left[\mathrm{X}^{2}\right]_{\text {in }}}
\end{aligned}
$$

allow reduction of the dimensions of the space of steady state characteristics to five: $\left[\mathrm{Na}^{+}\right]_{i n},\left[\mathrm{Cl}^{-}\right]_{i n}, J_{\mathrm{Na}}, J_{K}, J_{\text {pump }}$.

The correspondence table between permeability parameters and steady state characteristics of the model was calculated. The results of these calculations demonstrated that when the ratios between permeability parameters were constant $\left(P_{N a} / P_{K}=\right.$ const and $N_{\text {pump }} / P_{K}=$ const $)$ the steady states of the system differed only by the rates of ion fluxes $J_{i}(i=\mathrm{Na}$, $K$, pump) which is the direct consequence of the properties of the model differential equations. When all three permeability parameters were changed $n$-fold this caused $n$-fold change of the fluxes $J_{i}$, but the intracellular ion concentrations $\left(\left[\mathrm{Na}^{+}\right]_{i n}\right.$, $\left.\left[\mathrm{K}^{+}\right]_{i n},\left[\mathrm{Cl}^{-}\right]_{i n},\left[\mathrm{X}^{Z}\right]_{i n}\right)$ and the transmembrane potential difference $\left(E_{m}\right)$ remained unchanged. Therefore, it was possible to use the ratios of parameters $\left(P_{\mathrm{Na}} / P_{K}, N_{\text {pump }} / P_{K}\right)$ instead of the absolute values of parameters $\left(P_{N a}, P_{K}, N_{\text {pump }}\right)$. The wide range of parameter values, which we assume to exceed the range of possible permeability variations in living cells, was explored in simulations: $P_{\mathrm{Na}} / P_{K}$ was varied from $1 \times 10^{-3}$ to $1 \times 10^{1}$ and $N_{\text {pump }} / P_{K}$ was varied from $1 \times 10^{-9}$ to $6 \times 10^{-3}$ mol.s $/ \mathrm{cm}^{3}$. The subrange of the parameter values $\left(P_{N a} / P_{K}\right.$ and $\left.N_{\text {pump }} / P_{K}\right)$ for which the system could reach steady state was specified. The relation between the model parameters and steady state characteristics was obtained (Fig. 6). 
A

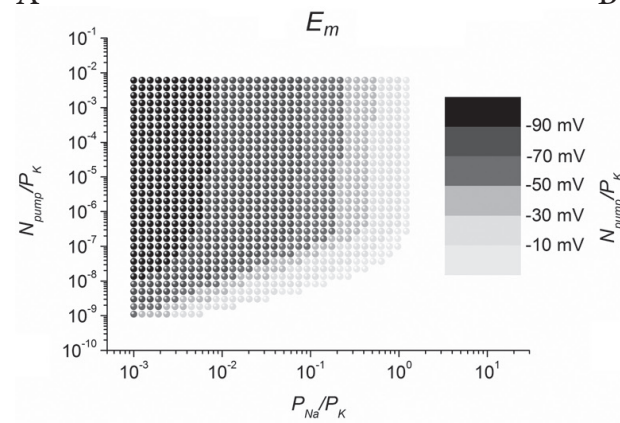

B

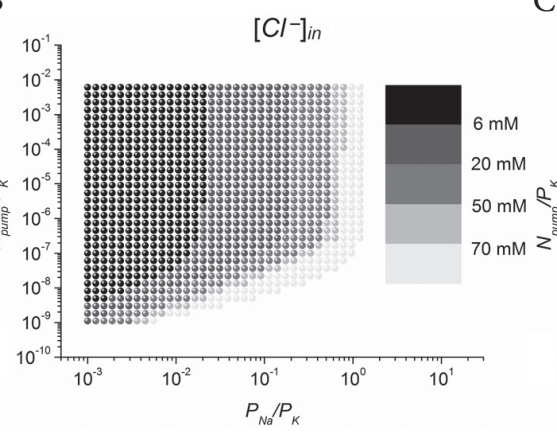

C

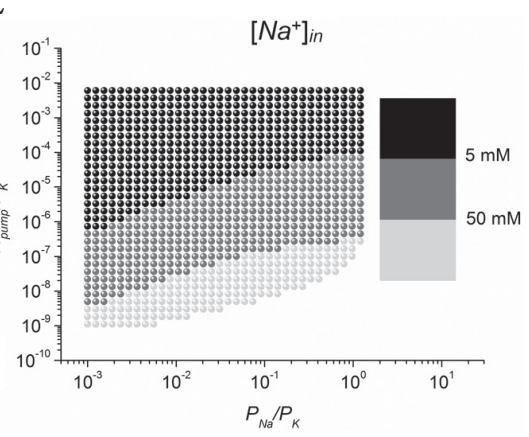

Figure 6. The dependence of the transmembrane potential difference $E_{m}(\mathbf{A})$, the intracellular chloride concentration $\left[\mathrm{Cl}^{-}\right]_{\text {in }}(\mathbf{B})$, and the intracellular sodium concentration $\left[\mathrm{Na}^{+}\right]_{\text {in }}(\mathbf{C})$ on the values of $P_{N a} / P_{K}$ and $N_{\text {pump }} / P_{K}$ obtained in simulations.

As a result, the unique correspondence between each point of two-dimensional space of parameters $\left(P_{N a} / P_{K}\right.$, $\left.N_{\text {pump }} / P_{K}\right)$ and each point of two-dimensional space of steady state characteristics $\left(\left[\mathrm{Na}^{+}\right]_{i n},\left[\mathrm{Cl}^{-}\right]_{i n}\right)$ was established. One-to-one mapping of the set of parameter values onto the set of steady state characteristic values obtained by the computer modeling allows for quantitative estimation of the rate of transmembrane transport of ions in real cells.

To estimate $P_{N a} / P_{K}$ and $N_{\text {pump }} / P_{K}$ ratios which are typical for OMCD cells it was necessary to define the values of intracellular sodium and chloride concentration $\left(\left[\mathrm{Na}^{+}\right]_{i n}\right.$, $\left.\left[\mathrm{Cl}^{-}\right]_{\text {in }}\right)$ in these cells. This was achieved on the basis of experimental data described earlier in this work. In the correspondence table between permeability parameters and steady state characteristics, the state was chosen that was the most similar to experimental estimates: $\left[\mathrm{Na}^{+}\right]_{\text {in }}=37.4 \mathrm{mM}$; $\left[\mathrm{Cl}^{-}\right]_{\text {in }}=32.5 \mathrm{mM}$. That stationary state corresponded to the following ratios of permeability parameters: $P_{N a} / P_{K}=0.32$; $N_{\text {pump }} / P_{K}=3.35 \times 10^{-7} \mathrm{~mol} \cdot \mathrm{s} / \mathrm{cm}^{3}$.

Further estimation of absolute values of permeability parameters was made on the basis of estimated ratios of permeability parameters. The ratios of permeability parameters were kept constant. This is imperative, as the steady state composition $\left(\left[\mathrm{Na}^{+}\right]_{i n},\left[\mathrm{Cl}^{-}\right]_{\text {in }}\right)$ of the model cell would otherwise have changed significantly.

The model simulations showed that if the chloride permeability $P_{C l}$ was varied from $1.0 \times 10^{-6} \mathrm{~cm} / \mathrm{s}$ to $5.0 \times 10^{-5}$ $\mathrm{cm} / \mathrm{s}$ there was no significant influence on the dynamics of intracellular sodium concentration $\left[\mathrm{Na}^{+}\right]_{\text {in }}$ (unpublished data). Thus at this step the chloride permeability $P_{C l}$ was equal to $1.0 \times 10^{-6} \mathrm{~cm} / \mathrm{s}$.

We needed to estimate only the proportionality coefficient $k$ in the follow equations: $P_{N a}=k P_{N a}^{k=1}, P_{K}=k P_{K}^{k=1}$ and $N_{\text {pump }}=k N_{\text {pump }}{ }^{k=1}$, where $P_{N a}^{k=1}=3.2 \times 10^{-7} \mathrm{~cm} / \mathrm{s}, P_{K}^{k=1}=$ $1.0 \times 10^{-6} \mathrm{~cm} / \mathrm{s}$ and $N_{\text {pump }}{ }^{k=1}=3.35 \times 10^{-13} \mathrm{~mol} / \mathrm{cm}^{2}$. Coefficient $k$ multiplies the permeability parameters, keeping $P_{N a} / P_{K}$ and $N_{\text {pump }} / P_{K}$ ratios constant. The value of $k$ was obtained on the basis of experimentally obtained dynamics of sodium concentration in cells placed in low-sodium medium $\left(\left[\mathrm{Na}^{+}\right]_{\text {out }}=9.4 \mathrm{mM}\right)$ (Fig. 7). The effect of low-sodium medium was simulated in the model by the variation of the parameters describing external ion concentrations: $\left[\mathrm{Na}^{+}\right]_{\text {out }}=9.4 \mathrm{mM},\left[\mathrm{K}^{+}\right]_{\text {out }}=4.2 \mathrm{mM},\left[\mathrm{Cl}^{-}\right]_{\text {out }}=130.7 \mathrm{mM}$, keeping $\Pi_{e}=280 \mathrm{mM}$ constant. The results of simulations were fitted to experimental data of sodium entry into the cell (following the increase of extracellular sodium concentration which caused the increase of intracellular sodium concentration), and the best-fit value of $k$ (and therefore

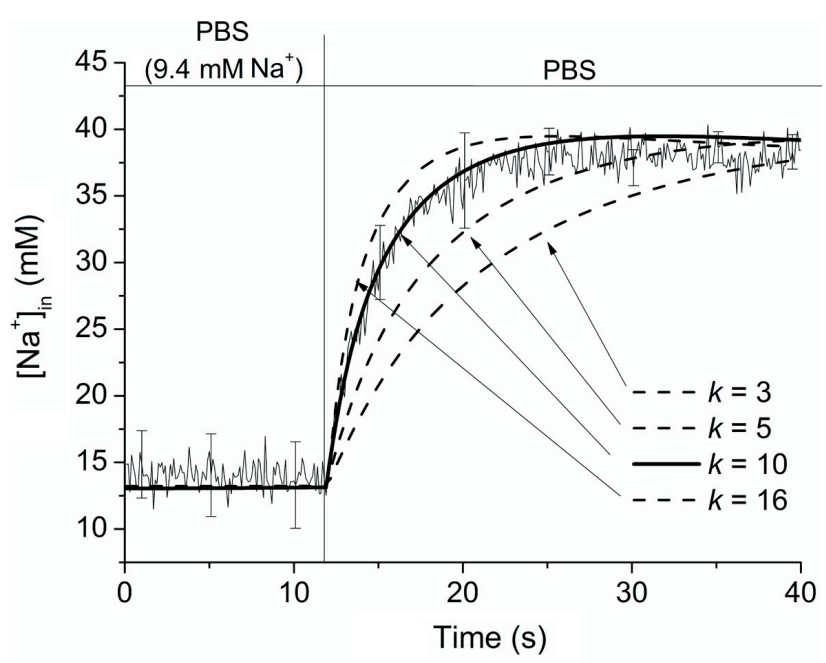

Figure 7. The dynamics of intracellular sodium concentration $\left[\mathrm{Na}^{+}\right]_{\text {in }}$ in OMCD principal cells following the transition from low-sodium medium $(9.4 \mathrm{mM})$ to isotonic phosphate buffered saline (PBS) (mean $\pm \mathrm{SE}, n=7$ ). Estimation of the absolute values of sodium and potassium permeabilities for OMCD principal cells. The results of modeling of intracellular sodium dynamics following increase of external sodium concentration with different values of $k$ are shown by dashed lines. The solid line shows the best-fit result of modeling to the experimental curve. 
the absolute values of $P_{N a}, P_{K}$ and $\left.N_{p u m p}\right)$ was obtained. The best-fit value of $k(k=10)$ was used to calculate the absolute values of $P_{\mathrm{Na}}=3.2 \times 10^{-6} \mathrm{~cm} / \mathrm{s} ; P_{K}=1.0 \times 10^{-5}$ $\mathrm{cm} / \mathrm{s} ; N_{\text {pump }}=3.35 \times 10^{-12} \mathrm{~mol} / \mathrm{cm}^{2}$. Also, the rates of transmembrane ion fluxes corresponding to the calculated parameter values have been derived: $J_{\mathrm{Na}}=7.41 \times 10^{-10}$ $\mathrm{mol} / \mathrm{cm}^{2} \cdot \mathrm{s}, J_{K}=-4.94 \times 10^{-10} \mathrm{~mol} / \mathrm{cm}^{2} \cdot \mathrm{s}, J_{\text {pump }}=2.47 \times$ $10^{-10} \mathrm{~mol} / \mathrm{cm}^{2} \cdot \mathrm{s}$.

Membrane chloride permeability $\left(P_{C l}\right)$ was estimated using the rate of relative volume change of a cell in $\mathrm{Cl}$-free medium. This estimation was based on the assumption that the rate of cell shrinkage in $\mathrm{Cl}$-free medium was proportional to the rate of chloride efflux, and that the $\mathrm{Cl}$ channels provided this efflux. The effect of $\mathrm{Cl}$-free solution was simulated by the change of parameters defining the composition of extracellular medium: $\left[\mathrm{Na}^{+}\right]_{\text {out }}=134.4 \mathrm{mM},\left[\mathrm{K}^{+}\right]_{\text {out }}=4.2$ $\mathrm{mM},\left[\mathrm{Cl}^{-}\right]_{\text {out }}=0 \mathrm{mM}$, keeping $\Pi_{e}=280 \mathrm{mM}$ constant. The calculations were based on the permeability parameter values $\left(P_{N a}, P_{K}\right.$ and $\left.N_{\text {pump }}\right)$ determined in the previous stage. The value of $P_{C l}=3.0 \times 10^{-6} \mathrm{~cm} / \mathrm{s}$ was estimated by comparing the experimental and simulated time curves of the relative cell volume (Fig. 5).

Calculated values of cell volume, intracellular ion concentrations, transmembrane potential difference, membrane ion permeabilities and rates of transmembrane osmolyte transport obtained by the biophysical model of OMCD principal cell are presented in Table 2 .

Table 2. Calculated values of cell physiological characteristics (cell volume, intracellular ion concentrations, transmembrane potential difference, membrane ion permeabilities and rates of transmembrane osmolyte transport) obtained by the biophysical model of an OMCD principal cell

\begin{tabular}{ll}
\hline \multicolumn{2}{l}{ Physiological characteristics of OMCD principal cell } \\
\hline$V$ & $9.65 \times 10^{-10} \mathrm{~cm}^{3}$ \\
{$\left[\mathrm{Na}^{+}\right]_{\text {in }}$} & $37.4 \mathrm{mM}$ \\
{$\left[\mathrm{K}^{+}\right]_{\text {in }}$} & $124 \mathrm{mM}$ \\
{$\left[\mathrm{Cl}^{-}\right]_{\text {in }}$} & $32.5 \mathrm{mM}$ \\
$E_{m}$ & $-0.037 \mathrm{~V}$ \\
$P_{\mathrm{Na}}$ & $3.2 \times 10^{-6} \mathrm{~cm} / \mathrm{s}$ \\
$P_{K}$ & $1.0 \times 10^{-5} \mathrm{~cm} / \mathrm{s}$ \\
$P_{\mathrm{Cl}}$ & $3.0 \times 10^{-6} \mathrm{~cm} / \mathrm{s}$ \\
$N_{\text {pump }}$ & $3.35 \times 10^{-12} \mathrm{~mol} / \mathrm{cm}^{2}$ \\
$J_{\mathrm{Na}}$ & $7.41 \times 10^{-10} \mathrm{~mol} / \mathrm{cm}^{2} \mathrm{~s}$ \\
$J_{K}$ & $-4.94 \times 10^{-10} \mathrm{~mol} / \mathrm{cm}^{2} \mathrm{~s}$ \\
$J_{\text {pump }}$ & $2.47 \times 10^{-10} \mathrm{~mol} / \mathrm{cm}^{2} \mathrm{~s}$ \\
\hline
\end{tabular}

The minus sign - designates the outward direction of ion flux (efflux); $J_{N a}$, transmembrane electrodiffusion flux of $\mathrm{Na}^{+} ; J_{K}$, transmembrane electrodiffusion flux of $\mathrm{K}^{+} ; j_{\text {pump }}, \mathrm{Na} / \mathrm{K}$ pump-mediated transmembrane flux (for other symbols, see Table 1).

\section{Discussion}

We proposed an approach to investigate ion and water transport across the plasma membrane of renal collecting duct (OMCD) principal cells. Fluorescent indicators were used to estimate the intracellular concentration of sodium and the cell volume dynamics of principal cells of isolated OMCD fragments. We also assessed the activity of KCC and NKCC cotransporters in this type of cells. Experimental data were analyzed with the help of a biophysical model describing transmembrane ion fluxes. This approach allowed us to quantitatively estimate physiological characteristics of cells for which experimental measurement is a difficult task.

It was important to take into account all the ion currents through transporters which made significant contributions to the total ion flux across the cell membrane. Ion cotransporters such as NKCC and KCC are widely expressed in vertebrate tissues, where they contribute to maintaining cell volume homeostasis (Hoffmann et al. 2009). Basolateral membrane localization of the NKCC1 protein and its involvement in solute uptake has been demonstrated in the principal cells of rat IMCD (Chou et al. 2008). Also, NKCC1 was detected using an immunocytochemical approach in the basolateral plasma membrane of a-intercalated cells of the cortical collecting duct (CCD), outer medulla, and the base region of the inner medulla (Ginns et al. 1996). Microperfusion studies of superficial distal tubules of rat (Ellison et al. 1986) and of isolated rabbit CCDs (Wingo 1989) have provided evidence for an electroneutral $\mathrm{K}^{+} \mathrm{Cl}^{-}$cotransport mechanism in the apical membrane of cells in the distal tubule. The activity of NKCC and KCC cotransporters in OMCD principal cells has not been investigated.

In our previous paper (Ilyaskin et al. 2011), the fluxes through KCC and NKCC cotransporters were included to the model system, but according to our current experimental results the contribution of NKCC and KCC cotransporters to the net transmembrane ion flux in OMCD principal cells is negligible and thus passive distribution of chloride ions across the cell membrane is assumed.

Accurate measurement of the intracellular chloride concentration is currently impossible, as the existing fluorescent indicators for chloride ions have low specificity (Jayaraman and Verkman 2000). The most precise and expensive experimental approach for exact determination of intracellular ion content is based upon energy-dispersive X-ray microanalysis (Gifford et al. 1990). In the present work, we performed quantitative estimation of intracellular chloride concentration indirectly by analysis of experimental data on the effect of $\mathrm{Cl}$-free medium on cell volume. Cells in the $\mathrm{Cl}$-free solution equilibrated to a relative cell volume equal to $0.77 \pm 0.03(n=10)$ (Fig. 5). The $\mathrm{Cl}$-free medium drives nearly all $\mathrm{Cl}^{-}$ions out of a cell and the flux of negatively charged chloride ions is coupled with positively charged 
ions to maintain electroneutrality. Therefore, the intracellular chloride content could be estimated as $11.5 \%$ of the total cellular osmolyte content, or $32.2 \pm 4.0 \mathrm{mM}$, assuming that the total intracellular ion concentration is $280 \mathrm{mM}$, that the osmotically inactive portion of the cell volume is small enough to be neglected, and that the intracellular amount of organic anions is unaffected during the incubation of cells in Cl-free medium. This estimation is in a satisfactory agreement with experimental evidence obtained by various approaches (Beck et al. 1988; Gifford et al. 1990). Given the passive chloride distribution between intracellular and extracellular space, the value of membrane potential $E_{m}$ can be estimated from the measured intracellular chloride concentration (approximately equal to $-40 \mathrm{mV}$ ). This estimate is close to the data obtained in previous studies on collecting duct cells (Stanton 1989; Pappas and Koeppen 1992) and may serve as an additional confirmation of the validity of our indirect approach.

The biophysical model used for analysis of experimental results belongs to the class of "Pump-leak models". These models were first introduced by Tosteson and Hoffman (Tosteson and Hoffman 1960). Subsequent development of such models was described by several authors (Jakobsson 1980; Hernandez and Cristina 1998; Fraser and Huang 2004). Various models of this type differ by the equations that govern transmembrane ion fluxes, and by the number of intracellular osmolytes and mechanisms of transmembrane transport considered (Keener and Sneyd 1998). It was shown by Hernandez (Hernandez 2007) that a general model capable of describing the basic aspects of the dynamics of the cell volume could be created. In that work several particular cases of the general model were shown which could be subdivided into two categories: symmetrical (non-polarized) and epithelial (polarized) cell models. Despite the difference between the two types of the general model, they share common characteristics regarding their steady states. It was demonstrated via the neighborhood stability analysis that the steady states of the model represented asymptotically stable configurations (Hernandez 2003, 2007). Benson (Benson et al. 2011) examined a natural extension of this general model to an arbitrary number of solutes or solute pathways and showed that this system was globally asymptotically stable. Further mathematical properties regarding the existence and stability of steady states of a general class of pump-leak models was discussed by Mori (Mori 2012). It was shown analytically that when the ion channel currents had a linear current-voltage relationship, there was at most one globally asymptotically stable steady state. If there were no steady states, the cell volume tended to infinity with time. It is worth mentioning that the model presented in the current work showed similar behavior.

Collecting duct principal cells are polarized and have two different cell surfaces, apical and basolateral, each with a different set of ion channels and carriers. The main function of these cells being included in the OMCD epithelia is to perform vectorial water and ion transport between tubular fluid and interstitium. The driving force for this transport is generated by transepithelial osmotic and ion electrochemical gradients. In the current work we study the water and electrolyte homeostasis of a single OMCD cell regardless of its role in transepithelial transport. Our experimental model is characterized by the absence of electrochemical transepithelial gradients, as the cells are placed to homogeneous medium. We conducted experiments on open-end portions of isolated OMCD fragments where apical and basolateral sides of cells were well-stirred and bathed with the same solution. A "symmetrical" type of biophysical model is therefore adequate to simulate the results obtained in our experiments. The model cell was treated as a symmetric entity (apical and basolateral side were not considered separately) bathed with homogenous solution, like in previously reported models (Hernandez and Chifflet 2000; Fraser and Huang 2004; Espelt et al. 2008). Thus our experimental design allowed us to use a simple "symmetrical" model to study polarized epithelial cells, which could be viewed as an advantage of the current approach.

A significant contribution to the development of epithelial cell models in the context of renal physiology was made by Weinstein (Weinstein 1997, 1999, 2000, 2001, 2003), who focused on the simulation of in vivo conditions and on modeling of cells as a part of the epithelial layer to answer the questions raised by the results of microperfusion experiments on renal tubules (Weinstein, 2003). He developed a mathematical model of the OMCD consisting only of a-intercalated cells (Weinstein 2000) and then updated it (Weinstein 2010) to include a population of principal cells that were identical to those of CCD. Models of cortical collecting duct (CCD) principal cells (Weinstein 1997, 1999, 2001) include not only main ion osmolytes but also several solutes which are important for intracellular regulation of $\mathrm{pH}$. In particular there are 12 permeant model solutes: $\mathrm{Na}^{+}$, $\mathrm{K}^{+}, \mathrm{Cl}^{-}, \mathrm{HCO}_{3}{ }^{-}, \mathrm{CO}_{2}, \mathrm{H}_{2} \mathrm{CO}_{3}, \mathrm{HPO}_{4}{ }^{2-}, \mathrm{H}_{2} \mathrm{PO}_{4}{ }^{-}, \mathrm{NH}_{3}$, $\mathrm{NH}_{4}{ }^{+}, \mathrm{H}^{+}$and urea (Weinstein 2001). Long term regulatory and metabolic processes such as the maintenance of cell acid-base homeostasis were out of the scope of the current work. The model considered was focused on the solute fluxes that play the main role in the maintenance of the cell water-electrolyte balance; therefore, only $\mathrm{Na}^{+}, \mathrm{K}^{+}$and $\mathrm{Cl}^{-}$fluxes were modeled. In addition, in the principal cell model by Weinstein fluxes through $\mathrm{NCC}\left(\mathrm{Na}^{+} \mathrm{Cl}^{-}\right), \mathrm{Na}^{+} / \mathrm{H}^{+}$ and $\mathrm{Cl}^{-} / \mathrm{HCO}_{3}{ }^{-}$were simulated. However, in these models the calculated values of fluxes through $\mathrm{NCC}, \mathrm{Na}^{+} / \mathrm{H}^{+}$and $\mathrm{Cl}^{-} / \mathrm{HCO}_{3}{ }^{-}$were insignificant in comparison with the passive ion fluxes and fluxes through $\mathrm{Na} / \mathrm{K}$-pump (Weinstein 1997, 1999, 2001). Therefore these fluxes were neglected in our model. The level of approximation accepted in the 
model comports the experimental protocol used in the current work. Using medium which was buffered by $\mathrm{Na}_{2} \mathrm{HPO}_{4}$ and $\mathrm{KH}_{2} \mathrm{PO}_{4}$ instead of $\mathrm{HCO}_{3}{ }^{-}$and $\mathrm{CO}_{2}$ we minimized the possible influence of corresponding transporters on cell behavior in ion substitution experiments.

The flux through the Na/K-pump $\left(J_{\text {pump }}\right)$ was simulated using the rate constants of the enzyme presented in (Hernandez and Chifflet 2000). The estimation of Na/K-pump parameters for OMCD principal cells (there were more than 15 constants to be determined) was outside the scope of the current work. But it is known that properties of $\mathrm{Na} / \mathrm{K}-\mathrm{AT}$ Pase, especially affinities to substrates, depend on the cell type and also could be influenced by the change of sodium concentration in extra- and intracellular medium (Soltoff and Mandel 1984). Changes of $\mathrm{Na} / \mathrm{K}$-pump properties were not considered in the present model.

The relation between the model parameters and steady state characteristics has been determined. A similar approach to systematic examination of the effect of permeability parameters on cellular characteristics in an epithelial model was introduced previously (Weinstein
1999). Analysis of the results has shown that our model allows performing adequate simulation of transmembrane transport in a real cell. In particular, the model corroborates the well-known observation that the value of the transmembrane potential difference $E_{m}$ is mainly defined by the $P_{N a} / P_{K}$ ratio (Fig. 6a). Increasing this ratio leads to membrane depolarization of the model cell. Calculations showed that if the value of $P_{N a} / P_{K}$ exceeded 1.5 , it led to membrane depolarization and unlimited increase of the model cell volume. It is obvious that the threshold level for the $P_{N a} / P_{K}$ ratio $\left(P_{N a} / P_{K}=1.5\right)$ results from the stoichiometry of the $\mathrm{Na} / \mathrm{K}$-pump. According to the equilibrium distribution of chloride ions between external and internal medium in the model, the stationary chloride concentration depended directly on the value of the transmembrane potential difference $E_{m}$. Thus, it showed similar dependence on permeability parameters as $E_{m}$ (Fig. 6b). The ratio of model parameters $N_{\text {pump }} / P_{K}$ represents the ratio between active and passive transport. This ratio defines the value of intracellular sodium concentration. Decreasing of this parameter causes sodium ions to enter into the model cell

Table 3. Comparison of physiological characteristics of kidney epithelial cells

\begin{tabular}{|c|c|c|c|}
\hline Characteristic & Value (this study) & Value (other studies) & References \\
\hline \multirow{4}{*}{$E_{m}$} & \multirow{4}{*}{$-37 \mathrm{mV}$ (calculated) } & Rabbit cultured OMCD cells: $-30 \div-40 \mathrm{mM}$ & (Pappas and Koeppen 1992) \\
\hline & & $\begin{array}{l}\text { Rat IMCD (voltage across basolateral membrane): } \\
-51.1 \mathrm{mV}\end{array}$ & (Stanton 1989) \\
\hline & & $\begin{array}{l}\text { Rabbit OMCD (inner stripe, voltage across basolateral } \\
\text { membrane): }-29.2 \pm 2.1 \mathrm{mV}\end{array}$ & (Koeppen 1985) \\
\hline & & $\begin{array}{l}\text { Rabbit OMCD (outer stripe, voltage across basolateral } \\
\text { membrane): } \\
\text { Cell type } 1:-30.1 \pm 2.4 \mathrm{mV} \\
\text { Cell type } 2:-63.7 \pm 2.7 \mathrm{mV}\end{array}$ & (Koeppen 1986) \\
\hline$\left[\mathrm{Na}^{+}\right]_{\text {in }}$ & $37.3 \pm 3.3 \mathrm{mM}$ (experimental) & $\begin{array}{l}\text { Principal cells of rat CCD (incubated for } 1 \mathrm{~h} \text { in vitro in } \\
\text { a modified Ringer solution, } 105 \mathrm{mM} \mathrm{Cl} \text { ): } 17.0 \mathrm{mM}\end{array}$ & (Gifford et al. 1990) \\
\hline$\left[K^{+}\right]_{\text {in }}$ & $124 \mathrm{mM}$ (calculated) & $\begin{array}{l}\text { Principal cells of rat CCD (incubated for } 1 \mathrm{~h} \text { in vitro in } \\
\text { a modified Ringer solution, } 105 \mathrm{mM} \mathrm{Cl} \text { ): } 192.5 \mathrm{mM}\end{array}$ & (Gifford et al. 1990) \\
\hline$\left[\mathrm{Cl}^{-}\right]_{\text {in }}$ & $32.2 \pm 4.0 \mathrm{mM}$ (experimental) & $\begin{array}{l}\text { Principal cells of rat CCD (incubated for } 1 \mathrm{~h} \text { in vitro in } \\
\text { a modified Ringer solution, } 105 \mathrm{mM} \mathrm{Cl} \text { ): } 17.8 \mathrm{mM}\end{array}$ & (Gifford et al. 1990) \\
\hline$[X]_{\text {in }}$ & $86 \mathrm{mM}$ (calculated) & $\begin{array}{l}\text { Primary culture of rat IMCD cells (osmolarity of the } \\
\text { culture medium } 300 \mathrm{mosmol} / \mathrm{l} \text { ): } 91 \mathrm{mosmol} / \mathrm{l}\end{array}$ & (Kinne et al. 2001) \\
\hline$P_{\mathrm{Na}}$ & $3.2 \times 10^{-6} \mathrm{~cm} / \mathrm{s}$ (calculated) & $\begin{array}{l}\text { Mathematical model of rat CCD: } \\
6.7 \times 10^{-6} \mathrm{~cm} / \mathrm{s}\end{array}$ & (Weinstein 2001) \\
\hline$P_{K}$ & $1.0 \times 10^{-5} \mathrm{~cm} / \mathrm{s}$ (calculated) & $\begin{array}{l}\text { Mathematical model of rat CCD: } \\
5.9 \times 10^{-5} \mathrm{~cm} / \mathrm{s}\end{array}$ & (Weinstein 2001) \\
\hline$P_{C l}$ & $3.0 \times 10^{-6} \mathrm{~cm} / \mathrm{s}$ (calculated) & $\begin{array}{l}\text { Mathematical model of rat CCD: } \\
6.7 \times 10^{-6} \mathrm{~cm} / \mathrm{s}\end{array}$ & (Weinstein 2001) \\
\hline$N_{\text {pump }} /$ cell & $2.0 \times 10^{7} /$ cell (calculated) & $\begin{array}{l}\text { Quantitation of }\left[{ }^{3} \mathrm{H}\right] \text { ouabain binding sites along the } \\
\text { rabbit nephron: } 1 \times 10^{7} \div 5 \times 10^{7} / \text { cell }\end{array}$ & (El Mernissi and Douce 1984) \\
\hline
\end{tabular}


until the intracellular sodium concentration equals extracellular sodium concentration $\left[\mathrm{Na}^{+}\right]_{\text {out }}$, which corresponds to the behaviour of the real cell upon $\mathrm{Na} / \mathrm{K}$-pump inhibition. It was also possible to select the region of permeability parameter space which corresponded to the steady states characterized by intracellular sodium concentration in the range 5-50 $\mathrm{mM}$ which was typical for living mammalian cells (Fig. 6c). The estimates of the ion permeabilities and fluxes in OMCD cells obtained in the current work are close to the data of other authors (see Table 3) (El Mernissi and Doucet 1984; Muto 2001; Weinstein 2000, 2001). In particular, the calculated values of membrane ion permeabilities for CCD principal cells (Weinstein 2001) and our predictions for OMCD principal cells have the same order of magnitude.

In conclusion, the results of our work show that using a model which simulates ion fluxes through the channels and transporters which are typical for the cell type under consideration allows for accurate estimation of cell physiological characteristics for which accurate experimental measurement is a difficult task.

\section{Appendix}

\section{Modeling the flux mediated by Na/K-pump}

The flux through the Na/K-pump $\left(J_{\text {pump }}\right)$ was derived from the kinetic model described in (Hernandez et al. 1989) using rate constants and other parameters of the $\mathrm{Na} / \mathrm{K}$-pump presented in (Hernandez and Chifflet 2000). The flux of ions

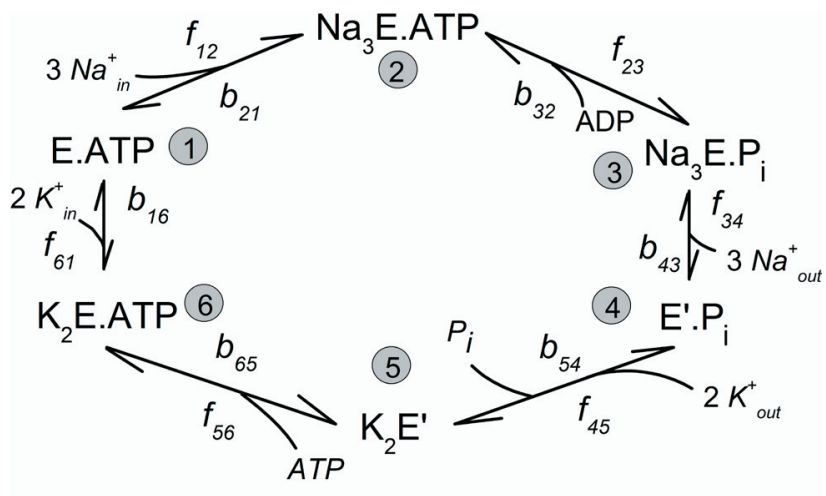

Figure 8. The diagram of $\mathrm{Na}^{+}$and $\mathrm{K}^{+}$transport mediated by the $\mathrm{Na} / \mathrm{K}$-ATPase (Hernandez and Chifflet 2000). E and E' are the different enzyme conformations; $1-6$ are the intermediate states of the enzyme; $\mathrm{Na}^{+}{ }_{\text {in }}, \mathrm{K}^{+}{ }_{\text {in }}, \mathrm{Na}^{+}{ }_{\text {out }}$ and $\mathrm{K}^{+}{ }_{\text {out }}$ are intracellular and extracellular $\mathrm{Na}^{+}$and $\mathrm{K}^{+}$, respectively; $f_{i j}$ and $b_{j i}$ are the rate constants of $i \rightarrow j$ (forward) and $j \rightarrow i$ (backward) transitions, respectively.

through the $\mathrm{Na} / \mathrm{K}$-pump $\left(J_{\text {pump }}\right)$ was calculated according to the following formula (the list of $\mathrm{Na} / \mathrm{K}$-pump parameters (Hernandez and Chifflet 2000) and their values are shown in Table 4, the diagram of $\mathrm{Na}^{+}$and $\mathrm{K}^{+}$transport mediated by the $\mathrm{Na} / \mathrm{K}$-ATPase is depicted in Fig. 8):

$$
J_{\text {pump }}=\frac{1}{\Sigma} N_{\text {pump }}(\alpha-\beta)
$$

where $N_{\text {pump }}$ is the membrane pump density, $\alpha$ is a function of the forward rate constants:

Table 4. Parameters of the Na/K-pump model (Hernandez and Chifflet 2000)

\begin{tabular}{lll}
\hline Parameters of Na/K-pump & & \\
\hline Total Na/K-pump membrane density & $N_{\text {pump }}$ & Based on the experimental data \\
Intracellular ATP concentration & {$[A T P]_{\text {in }}$} & $5.0 \mathrm{mM}$ \\
Intracellular ADP concentration & {$[A D P]_{\text {in }}$} & $6.0 \times 10^{-5} \mathrm{M}$ \\
Intracellular concentration of phosphate ion & {$\left[P_{i}\right]_{\text {in }}$} & $4.95 \mathrm{mM}$ \\
\cline { 2 - 3 } & $f_{12}$ & $2.5 \times 10^{20} \mathrm{~mol}^{-3} \mathrm{~cm}^{9} \mathrm{~s}^{-1}$ \\
& $f_{23}$ & $10^{4} \mathrm{~s}^{-1}$ \\
& $f_{34}{ }^{0}$ & $360 \mathrm{~s}^{-1}$ \\
& $f_{45}$ & $1.5 \times 10^{13} \mathrm{~mol}^{-2} \mathrm{~cm}^{6} \mathrm{~s}^{-1}$ \\
& $f_{56}$ & $2 \times 10^{9} \mathrm{~mol}^{-1} \mathrm{~cm}^{3} \mathrm{~s}^{-1}$ \\
Rate constants of forward $(f)$ and backward $(b)$ & $f_{61}$ & $1.15 \times 10^{4} \mathrm{~s}^{-1}$ \\
reactions & $b_{21}$ & $424563 \mathrm{~s}^{-1}$ \\
& $b_{32}$ & $10^{8} \mathrm{~mol}^{-1} \mathrm{~cm}^{3} \mathrm{~s}^{-1}$ \\
& $b_{43}{ }^{0}$ & $8.5 \times 10^{12} \mathrm{~mol}^{-3} \mathrm{~cm}^{9} \mathrm{~s}^{-1}$ \\
& $a$ & $2 \times 10^{8} \mathrm{~mol}^{-1} \mathrm{~cm}^{3} \mathrm{~s}^{-1}$ \\
& $b_{65}$ & $30 \mathrm{~s}^{-1}$ \\
& $b_{16}$ & $6 \times 10^{14} \mathrm{~mol}^{-2} \mathrm{~cm}^{6} \mathrm{~s}^{-1}$ \\
\hline
\end{tabular}

* the final value of this parameter is shown in Table 2. 


$$
\begin{aligned}
& \alpha=a_{12} a_{23} a_{34} a_{45} a_{56} a_{61} \\
& a_{12}=f_{12}\left[N a^{+}\right]_{i n}^{3} \\
& a_{23}=f_{23} \\
& a_{34}=f_{34} \\
& a_{45}=f_{45}\left[K^{+}\right]_{\text {out }}^{2} \\
& a_{56}=f_{56}[A T P]_{\text {in }} \\
& a_{61}=f_{61}
\end{aligned}
$$

$\beta$ is a function of the backward rate constants:

$$
\begin{aligned}
& \beta=a_{21} a_{32} a_{43} a_{54} a_{65} a_{16} \\
& a_{21}=b_{21} \\
& a_{32}=b_{32}[A D P]_{\text {in }} \\
& a_{43}=b_{43}\left[\mathrm{Na}^{+}\right]_{\text {out }}^{3} \\
& a_{54}=b_{54}\left[P_{i}\right]_{\text {in }} \\
& a_{65}=b_{65} \\
& a_{16}=b_{16}\left[\mathrm{~K}^{+}\right]_{\text {in }}^{2}
\end{aligned}
$$

and $\Sigma$ is the function of all rate constants and ligand concentrations implemented in the kinetic scheme (Hernandez et al. 1989):

$$
\begin{aligned}
& \Sigma=A_{1}+A_{2}+A_{3}+A_{4}+A_{5}+A_{6} \\
& A_{1}=a_{23} a_{34} a_{45} a_{56} a_{61}+a_{34} a_{45} a_{56} a_{61} a_{21}+a_{45} a_{56} a_{61} a_{21} a_{32}+ \\
& +a_{56} a_{61} a_{21} a_{32} a_{43}+a_{61} a_{21} a_{32} a_{43} a_{54}+a_{21} a_{32} a_{43} a_{54} a_{65} \\
& A_{2}=a_{12} a_{34} a_{45} a_{56} a_{61}+a_{12} a_{45} a_{56} a_{61} a_{32}+a_{12} a_{56} a_{61} a_{32} a_{43}+ \\
& +a_{12} a_{61} a_{32} a_{43} a_{54}+a_{12} a_{32} a_{43} a_{54} a_{65}+a_{32} a_{43} a_{54} a_{65} a_{16} \\
& A_{3}=a_{12} a_{23} a_{45} a_{56} a_{61}+a_{12} a_{23} a_{56} a_{61} a_{43}+a_{12} a_{23} a_{61} a_{43} a_{54}+ \\
& +a_{12} a_{23} a_{43} a_{54} a_{65}+a_{23} a_{43} a_{54} a_{65} a_{16}+a_{21} a_{43} a_{54} a_{65} a_{16} \\
& A_{4}=a_{12} a_{23} a_{34} a_{56} a_{61}+a_{12} a_{23} a_{34} a_{61} a_{54}+a_{12} a_{23} a_{34} a_{54} a_{65}+ \\
& +a_{23} a_{34} a_{54} a_{65} a_{16}+a_{34} a_{21} a_{54} a_{65} a_{16}+a_{21} a_{32} a_{54} a_{65} a_{16} \\
& A_{5}=a_{12} a_{23} a_{34} a_{45} a_{61}+a_{12} a_{23} a_{34} a_{45} a_{65}+a_{23} a_{34} a_{45} a_{65} a_{16}+ \\
& +a_{34} a_{45} a_{21} a_{65} a_{16}+a_{45} a_{21} a_{32} a_{65} a_{16}+a_{21} a_{32} a_{43} a_{65} a_{16} \\
& A_{6}=a_{12} a_{23} a_{34} a_{45} a_{56}+a_{23} a_{34} a_{45} a_{56} a_{16}+a_{34} a_{45} a_{56} a_{21} a_{16}+ \\
& +a_{45} a_{56} a_{21} a_{32} a_{16}+a_{56} a_{21} a_{32} a_{43} a_{16}+a_{21} a_{32} a_{43} a_{54} a_{16} .
\end{aligned}
$$

The rate constants $f_{34}$ and $b_{43}$ are assumed to depend on the value of membrane potential $E_{m}$ (Hernandez and Chifflet 2000):

$$
\begin{aligned}
& f_{34}=f_{34}^{0} \exp \left(\frac{F E_{m}}{2 R T}\right) \\
& b_{43}=b_{43}^{0} \exp \left(-\frac{F E_{m}}{2 R T}\right)
\end{aligned}
$$

\section{Determination of $E_{m}$ using the QN method}

The value of $E_{m}$ could be determined employing the electroneutral condition:

$$
-J_{\text {pump }}+J_{N a}+J_{K}-J_{C l}=0
$$

Using expressions (5-7) describing passive $\mathrm{Na}^{+}, \mathrm{K}^{+}$and $\mathrm{Cl}^{-}$fluxes and the formulation for the flux through $\mathrm{Na} / \mathrm{K}-$ pump (8) (see above), the following expression for $E_{m}$ can be derived (Hernandez and Chifflet 2000), * see formula on the bottom, where $u$ and $\varepsilon(u)$ are the same as in Eqs. (5) - (7). This transcendental equation was solved by iteration; each approximation was found as the right-hand part computed using the previous approximation. The iterations were terminated when two successive values differed by less than $10^{-10} \mathrm{~V}$.

Acknowledgements. This work was supported by RFBR grants \#12-04-00369-a, \#12-04-00370-a and \#12-04-31298.

\section{References}

Bachmann S., Bostanjoglo M., Schmitt R., Ellison D. H. (1999): Sodium transport-related proteins in the mammalian distal nephron - distribution, ontogeny and functional aspects. Anat. Embryol. 200, 447-468 http://dx.doi.org/10.1007/s004290050294

Beck F. X., Dörge A., Rick R., Schramm M., Thurau K. (1988): The distribution of potassium, sodium and chloride across the apical membrane of renal tubular cells: effect of acute metabolic alkalosis. Pflügers Arch. 411, 259-267

http://dx.doi.org/10.1007/BF00585112

Bens M., Vandewalle A. (2008): Cell models for studying renal physiology. Pflügers Arch. 457, 1-15 http://dx.doi.org/10.1007/s00424-008-0507-4

Benson J., Chicone C., Critser J. (2011): A general model for the dynamics of cell volume, global stability, and optimal control. J. Math. Biol. 63, 339-359

$$
E_{m}=\frac{R T}{F} \ln \left(\frac{\left(P_{\text {Na }}\left[N a^{+}\right]_{\text {out }}+P_{K}\left[K^{+}\right]_{\text {out }}+P_{C l}\left[C l^{-}\right]_{\text {in }}\right) \varepsilon(u)+\frac{N_{\text {pump }}}{\Sigma} a_{21} a_{32} b_{43}^{0}\left[\mathrm{Na}^{+}\right]_{\text {out }}^{3} a_{54} a_{65} a_{16}}{\left(P_{N a}\left[N a^{+}\right]_{\text {in }}+P_{K}\left[K^{+}\right]_{\text {in }}+P_{C l}\left[C l^{-}\right]_{\text {out }}\right) \varepsilon(u)+\frac{N_{\text {pump }}}{\Sigma} a_{12} a_{23} f_{34}^{0} a_{45} a_{56} a_{61}}\right)
$$


http://dx.doi.org/10.1007/s00285-010-0374-4

Burg M. B. (1972): Perfusion of isolated renal tubules. Yale J. Biol. Med. 45, 321-326

Chou C. L., Yu M. J., Kassai E. M., Morris R. G., Hoffert J. D., Wall S. M., Knepper M. A. (2008): Roles of basolateral solute uptake via NKCC1 and of myosin II in vasopressin-induced cell swelling in inner medullary collecting duct. Am. J. Physiol. Renal. Physiol. 295, F192-201 http://dx.doi.org/10.1152/ajprenal.00011.2008

Despa S., Vecer J., Steels P., Ameloot M. (2000): Fluorescence lifetime microscopy of the $\mathrm{Na}+$ indicator Sodium Green in HeLa cells. Anal. Biochem. 281, 159-175 http://dx.doi.org/10.1006/abio.2000.4560

Duc C., Farman N., Canessa C. M., Bonvalet J. P., Rossier B. C. (1994): Cell-specific expression of epithelial sodium channel $\alpha, \beta$, and $\gamma$ subunits in aldosterone-responsive epithelia from the rat: localization by in situ hybridization and immunocytochemistry. J. Cell. Biol. 127, 1907-1921 http://dx.doi.org/10.1083/jcb.127.6.1907

El Mernissi G., Doucet A. (1984): Quantitation of [3H]ouabain binding and turnover of Na-K-ATPase along the rabbit nephron. Am. J. Physiol. Renal. Physiol. 247, F158-167

Ellison D. H., Velazquez H., Wright F. S. (1986): Unidirectional potassium fluxes in the renal distal tubule: effects of chloride and barium. Am. J. Physiol. Renal. Physiol. 250, F885-894

Espelt M. V., Alleva K., Amodeo G., Krumschnabel G., Rossi R. C., Schwarzbaum P. J. (2008): Volumetric response of vertebrate hepatocytes challenged by osmotic gradients: a theoretical approach. Comp. Biochem. Physiol. B 50, 103-111 http://dx.doi.org/10.1016/j.cbpb.2008.02.001

Feraille E., Doucet A. (2001): Sodium-potassium-adenosinetriphosphatase-dependent sodium transport in the kidney: hormonal control. Physiol. Rev. 81, 345-418

Fraser J. A., Huang C. L. (2004): A quantitative analysis of cell volume and resting potential determination and regulation in excitable cells. J. Physiol. 559, 459-478

http://dx.doi.org/10.1113/jphysiol.2004.065706

Frindt G., Palmer L. (1987): Ca-activated K channel in apical membrane of mammalian CCT, and their role in K secretion. Am. J. Physiol. Renal. Physiol. 252, F458-467

Frindt G., Palmer L. (1989): Low-conductance K channels in apical membrane of rat cortical collecting tubule. Am. J. Physiol. Renal. Physiol. 256, F143-151

Frindt G., Ergonul Z., Palmer L. G. (2007): Na channel expression and activity in the medullary collecting duct of rat kidney. Am. J. Physiol. Renal. Physiol. 292, F1190-1196 http://dx.doi.org/10.1152/ajprenal.00399.2006

Gifford J. D., Galla J. H., Luke R. G., Rick R. (1990): Ion concentrations in the rat CCD: differences between cell types and effect of alkalosis. Am. J. Physiol. 259, F778-782

Ginns S. M., Knepper M. A., Ecelbarger C. A., Terris J., He X., Coleman R. A., Wade J. B. (1996): Immunolocalization of the secretory isoform of $\mathrm{Na}-\mathrm{K}-\mathrm{Cl}$ cotransporter in rat renal intercalated cells. J. Am. Soc. Nephrol. 7, 2533-2542

Goldman D. E. (1943): Potential, impedance and rectification in membranes. J. Gen. Physiol. 27, 37-60 http://dx.doi.org/10.1085/jgp.27.1.37
Hernandez J., Fischbarg J., Liebovitch L. (1989): Kinetic model of the effects of electrogenic enzymes on the membrane potential. J. Theor. Biol. 137, 113-125

http://dx.doi.org/10.1016/S0022-5193(89)80153-5

Hernandez J., Cristina E. (1998): Modeling cell volume regulation in nonexcitable cells: the roles of the $\mathrm{Na}+$ pump and of cotransport systems. Am. J. Physiol. Cell. Physiol. 275, 1067-1080

Hernandez J., Chifflet S. (2000): Electrogenic properties of the sodium pump in a dynamic model of membrane transport. Membr. Biol. 176, 41-52 http://dx.doi.org/10.1007/s002320001074

Hernandez J. (2003): Stability properties of elementary dynamic models of membrane transport. Bull. Math. Biol. 65, 175-197 http://dx.doi.org/10.1006/bulm.2002.0325

Hernandez J. (2007) A general model for the dynamics of the cell volume. Bull. Math. Biol. 69, 1631-1648 http://dx.doi.org/10.1007/s11538-006-9183-8

Hodgkin A., Katz B. (1949): The effect of sodium ions on the electrical activity of the giant axon of the squid. J. Physiol. 108, 37-77

Hoffmann E. K., Lambert I. H., Pedersen S. F. (2009): Physiology of cell volume regulation in vertebrates. Physiol. Rev. 89, 193-277 http://dx.doi.org/10.1152/physrev.00037.2007

Ilyaskin A. V., Baturina G. S., Medvedev D. A., Ershov A. P., Solenov E. I. (2011): Study of the reaction of kidney collecting duct principal cells to hypotonic shock. Experiment and mathematical model. Biophysics 56, 516-524 (original text in Russian: 550-560)

Jakobsson E. (1980): Interactions of cell volume, membrane potential, and membrane transport parameters. Am. J. Physiol. 238, C196-206

Jayaraman S., Verkman A. S. (2000): Quenching mechanism of quinolinium-type chloride-sensitive fluorescent indicators. Biophys. Chem. 85, 49-57 http://dx.doi.org/10.1016/S0301-4622(00)00146-0

Keener J., Sneyd J. (1998): Mathematical Physiology. SpringerVerlag, New York

Kinne R. K. H., Kipp H., Ruhfus B., Wehner F., Boese S. H., Kinne-Saffran E. (2001): Organic osmolyte channels in the renal medulla: their properties and regulation. Amer. Zool. 41, 728-733 http://dx.doi.org/10.1668/0003-1569(2001)041[0728:OOCITR]2.0.CO;2

Koeppen B. M. (1985): Conductive properties of the rabbit outer medullary collecting duct: inner stripe. Am. J. Physiol. 248, F500-506

Koeppen B. M. (1986): Conductive properties of the rabbit outer medullary collecting duct: outer stripe. Am. J. Physiol. 250, F70-76

Kuwahara M., Sasaki S., Marumo F. (1991): Cl-HCO3 exchange and $\mathrm{Na}-\mathrm{HCO} 3$ symport in rabbit outer medullary collecting duct cells. Am. J. Physiol. 260, F635-642

Loffing J., Kaissling B. (2003): Sodium and calcium transport pathways along the mammalian distal nephron: from rabbit to human. Am. J. Physiol. Renal. Physiol. 284, F628-643

Meuwis K., Boens N., De Schryver F. C., Gallay J., Vincent M. (1995): Photophysics of the fluorescent K+ indicator PBFI. Biophys. J. 68, 2469-2473 
http://dx.doi.org/10.1016/S0006-3495(95)80428-5

Mori Y. (2012): Mathematical properties of pump-leak models of cell volume control and electrolyte balance. J. Math. Biol. 65, 875-918 http://dx.doi.org/10.1007/s00285-011-0483-8

Muto S. (2001): Potassium transport in the mammalian collecting duct. Physiol. Rev. 81, 85-116

Najjar F., Zhou H., Morimoto T., Bruns J. B., Li H. S., Liu W. Kleyman T. R., Satlin L. M. (2005): Dietary K+ regulates apical membrane expression of maxi-K channels in rabbit cortical collecting duct. Am. J. Physiol. Renal. Physiol. 289, F922-932 http://dx.doi.org/10.1152/ajprenal.00057.2005

Pappas C. A., Koeppen B. M. (1992): Electrophysiological properties of cultured outer medullary collecting duct cells. Am. J. Physiol. 263, F1004-1010

Pisitkun T., Bieniek J., Tchapyjnikov D., Wang G., Wu W. W., Shen R. F., Knepper M. A. (2006): High-throughput identification of IMCD proteins using LC-MS/MS. Physiol. Genomics 25, 263-276 http://dx.doi.org/10.1152/physiolgenomics.00214.2005

Sansom S. C., La B. Q., Carosi S. L. (1990): Double-barreled chloride channels of collecting duct basolateral membrane. Am. J. Physiol. 259, F46-52

Solenov E. I., Watanabe H., Manley G. T., Verkman A. S. (2004): Sevenfold-reduced osmotic water permeability in primary astrocyte cultures from AQP-4-deficient mice, measured by a fluorescence quenching method. Am. J. Physiol. Cell. Physiol. 286, C426-432 http://dx.doi.org/10.1152/ajpcell.00298.2003

Soltoff S. P., Mandel L.J. (1984): Active ion transport in the renal proximal tubule. II. Ionic dependence of the Na pump. J. Gen. Physiol. 84, 623-642 http://dx.doi.org/10.1085/jgp.84.4.623

Stanton B. A (1989): Characterization of apical and basolateral membrane conductances of rat inner medullary collecting duct. Am. J. Physiol. 256, F862-868

Todd-Turla K. M., Rusvai E., Náray-Fejes-Tóth A., Fejes-Tóth G. (1996): CFTR expression in cortical collecting duct cells. Am. J. Physiol. 270, F237-244

Tosteson D., Hoffman J. (1960): Regulation of cell volume by active cation transport in high and low potassium sheep red cells. J. Gen. Physiol. 44, 169-194

http://dx.doi.org/10.1085/jgp.44.1.169
Uawithya P., Pisitkun T., Ruttenberg B. E., Knepper M. A. (2008): Transcriptional profiling of native inner medullary collecting duct cells from rat kidney. Physiol. Genomics 32, 229-253 http://dx.doi.org/110.1152/physiolgenomics.00201.2007

Wakamatsu S., Nonoguchi H., Ikebe M., Machida K., Izumi Y., Memetimin H., Nakayama Y., Nakanishi T., Kohda Y., Tomita K. (2009): Vasopressin and hyperosmolality regulate NKCC1 expression in rat OMCD. Hypertens. Res. 32, 481-487 http://dx.doi.org/10.1038/hr.2009.52

Weinstein A. (1997): Dynamics of cellular homeostasis: recovery time for a perturbation from equilibrium. Bull. Math. Biol. 59, 451-481 http://dx.doi.org/10.1007/BF02459460

Weinstein A. (1999): Modeling epithelial cell homeostasis: steadystate analysis. Bull. Math. Biol. 61, 1065-1091 http://dx.doi.org/10.1006/bulm.1999.0127

Weinstein A. (2000): A mathematical model of the outer medullary collecting duct of the rat. Am. J. Physiol. Renal. Physiol. 279, F24-45

Weinstein A. (2001): A mathematical model of rat cortical collecting duct: determinants of the transtubular potassium gradient. Am. J. Physiol. Renal. Physiol. 280, F1072-1092

Weinstein A. (2003): Mathematical models of renal fluid and electrolyte transport: acknowledging our uncertainty. Am. J. Physiol. Renal. Physiol. 284, F871-884

Weinstein A. (2010): A mathematical model of rat ascending Henle limb. III. Tubular function. Am. J. Physiol. Renal. Physiol. 298, F543-556 http://dx.doi.org/10.1152/ajprenal.00232.2009

Wetzel R. K., Sweadner K. J. (2001): Immunocytochemical localization of Na-K-ATPase alpha- and gamma-subunits in rat kidney. Am. J. Physiol. Renal. Physiol. 281, F531-545

Wingo C. S. (1989): Potassium secretion by the cortical collecting tubule:effects of $\mathrm{Cl}$ gradients and ouabain. Am. J. Physiol. Renal. Physiol. 256, F306-313

Zarogiannis S. G., Ilyaskin A. V., Baturina G. S., Katkova L. E., Medvedev D. A., Karpov D. I., Ershov A. P., Solenov E. I. (2013): Regulatory volume decrease of rat kidney principal cells after successive hypo-osmotic shocks. Math. Biosci. 244, 176-187 http://dx.doi.org/10.1016/j.mbs.2013.05.007

Received: February 27, 2013

Final version accepted: July 30, 2013 